\title{
Diabetic cardiomyopathy: pathophysiology and clinical features
}

\author{
Takayuki Miki $\cdot$ Satoshi Yuda $\cdot$ Hidemichi Kouzu $•$ \\ Tetsuji Miura
}

Published online: 28 March 2012

(c) The Author(s) 2012. This article is published with open access at Springerlink.com

\begin{abstract}
Since diabetic cardiomyopathy was first reported four decades ago, substantial information on its pathogenesis and clinical features has accumulated. In the heart, diabetes enhances fatty acid metabolism, suppresses glucose oxidation, and modifies intracellular signaling, leading to impairments in multiple steps of excitationcontraction coupling, inefficient energy production, and increased susceptibility to ischemia/reperfusion injury. Loss of normal microvessels and remodeling of the extracellular matrix are also involved in contractile dysfunction of diabetic hearts. Use of sensitive echocardiographic techniques (tissue Doppler imaging and strain rate imaging) and magnetic resonance spectroscopy enables detection of diabetic cardiomyopathy at an early stage, and a combination of the modalities allows differentiation of this type of cardiomyopathy from other organic heart diseases. Circumstantial evidence to date indicates that diabetic cardiomyopathy is a common but frequently unrecognized pathological process in asymptomatic diabetic patients. However, a strategy for prevention or treatment of diabetic cardiomyopathy to improve its prognosis has not yet been established. Here, we review both basic and clinical studies on diabetic cardiomyopathy and summarize problems remaining to be solved for improving management of this type of cardiomyopathy.
\end{abstract}

Keywords Diabetes mellitus - Heart failure · Pathophysiology $\cdot$ Infarct size $\cdot$ Signal transduction . Therapy

T. Miki $\cdot$ S. Yuda $\cdot$ H. Kouzu $\cdot$ T. Miura $(\bowtie)$ Division of Cardiology, Second Department of Internal Medicine, School of Medicine, Sapporo Medical University, South-1 West-16, Chuo-ku, Sapporo 060-8543, Japan e-mail: miura@sapmed.ac.jp

\section{Introduction}

The number of patients with diabetes has been increasing worldwide in the past two decade, and these patients are predisposed to serious cardiovascular morbidity and mortality [1]. The impacts of diabetes on the development of atherosclerotic vascular diseases have been established, and results of recent clinical trials have indicated that not only hyperglycemia but also other risk factors need to be controlled for preventing atherosclerotic vascular events in diabetic patients $[2,3]$. On the other hand, non-ischemic heart failure associated with diabetes has received much less attention than coronary and cerebral vascular events.

Population-based studies have shown that the risk of heart failure is increased two- to threefold by diabetes $[4,5]$. The presence of diabetes substantially accelerates development of heart failure in patients with myocardial infarction [6, 7], hypertension [8], or atrial fibrillation [9], leading to poorer prognosis. Diabetes predicts poor prognosis independently of coronary artery disease and level of left ventricular ejection fraction (LVEF) in heart failure patients $[10,11]$. However, the concept of "diabetic cardiomyopathy" is still controversial, and a specific strategy to prevent or treat heart failure associated with diabetes has not been established. In this article, we review results from recent basic and clinical studies regarding "diabetic cardiomyopathy" and discuss its pathogenesis (Figs. 1, 2), diagnosis, and management. Although type 1 diabetes mellitus (T1DM) and type 2 diabetes mellitus (T2DM) differ in etiology and metabolic profiles, the two types share many features of cardiomyopathy. In this review, we mainly focus on myocardial changes that are commonly observed in both T1DM and T2DM and briefly discuss their differences if applicable. 


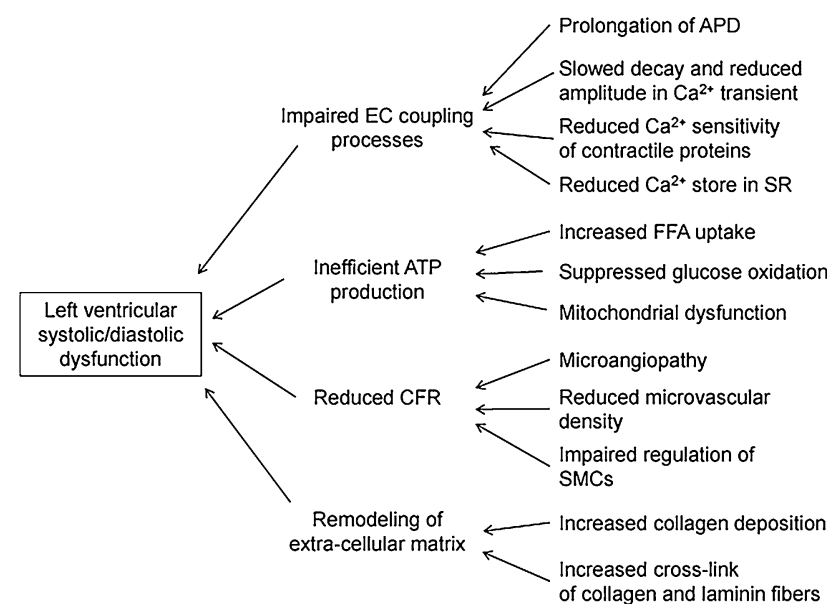

Fig. 1 Proposed mechanisms of contractile dysfunction by diabetes. $E C$ coupling excitation-contraction coupling, $A P D$ action potential duration, $S R$ sarcoplasmic reticulum, $F F A$ free fatty acid, $C F R$ coronary flow reserve, $S M C$ smooth muscle cell

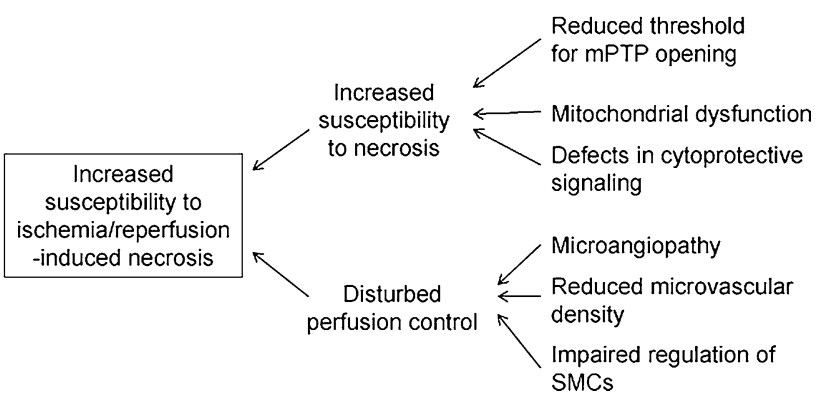

Fig. 2 Proposed mechanisms of diabetes-induced increase in susceptibility of the myocardium to ischemia/reperfusion-induced infarction. $m P T P$ mitochondrial permeability transition pore, $S M C$ smooth muscle cell

\section{Definition and clinical phenotype of diabetic cardiomyopathy}

Definition of diabetic cardiomyopathy

"Diabetic cardiomyopathy" is a concept that was introduced in 1972 by Rubler et al. [12], who examined pathology of four autopsy cases with diabetic glomerulosclerosis and no known cause of heart failure. The current typical definition of diabetic cardiomyopathy comprises structural and functional abnormalities of the myocardium in diabetic patients without coronary artery disease or hypertension [13]. Obviously, however, this type of cardiomyopathy should be present also in diabetics with coronary artery disease and/or hypertension, though it is difficult to separately assess the contribution of diabetic cardiomyopathy to overall ventricular dysfunction in such cases.

Interstitial and perivascular fibrosis is a histological hallmark of diabetic cardiomyopathy $[12,14,15]$, and the extent of fibrosis correlates with heart weight [15]. In addition to the increase in collagen deposition, cross-linking of collagen fibers may be increased by diabetes, contributing to reduction in ventricular compliance [16]. Clinical evidence to support this notion is actually sparse, but some studies [17-19] indicated that glycation of collagen fibers is indeed increased in hearts of diabetic patients.

"Cardiomyocyte hypertrophy" in diabetic cardiomyopathy is referred to in some earlier reviews, but its contribution to "ventricular hypertrophy" is not clear. Human myocardium biopsied at the time of coronary bypass surgery showed an increased cross-sectional area (CSA) of cardiomyocytes and interstitial fibrosis in diabetic patients compared with those in non-diabetics [20]. However, human biopsy studies by Yarom et al. [21] and Kawaguchi et al. [22] showed that the average myocyte diameter was not significantly increased by diabetes alone. Photographs of the histology of autopsy cases presented in earlier reports [12, 14, 15] show hypertrophic cardiomyocytes mixed with atrophic ones in diabetic cardiomyopathy. Increase in the CSA of cardiomyocytes with or without interstitial fibrosis has been reported for different animal models of T1DM and T2DM [23-25], but significant reduction in the CSA of cardiomyocyte was observed in a model of T1DM, Akita $\left(\right.$ Ins $\left.^{2 \mathrm{WT} / \mathrm{C} 96 \mathrm{Y}}\right)$ mouse [26]. Taken together, cardiomyocyte hypertrophy appears to be a frequently observed feature but not a requisite of diabetic cardiomyopathy. We speculate that long-standing metabolic derangements and modification of microcirculation (see section "Abnormalities in microvasculature" below) by diabetes induce different levels of hypertrophy, atrophy, and loss of cardiomyocytes in the myocardium depending on the duration of diabetes and/or co-morbidities such as hypertension.

Although it has not been included in the definition, increased susceptibility to ischemia/reperfusion injury may be an important feature of diabetic cardiomyopathy. Two clinical studies showed that myocardial infarct size after coronary reperfusion therapy was larger by $30-80 \%$ in diabetic patients than in non-diabetic patients [27, 28]. The difference was observed even though coronary blood flow was similarly restored by percutaneous coronary intervention in the diabetic and non-diabetic groups [27].

Clinical phenotype of diabetic cardiomyopathy

\section{Ventricular morphology}

Previous studies using transthoracic echocardiography (TTE) has indicated that diabetes (mostly T2DM) is associated with left ventricular (LV) hypertrophy or concentric $\mathrm{LV}$ remodeling (i.e., increased $\mathrm{LV}$ mass [LVM]-to-LV end-diastolic volume ratio) in females but not consistently 
in males [29-34]. However, TTE is not always suitable for elderly and/or obese patients, in whom image quality is frequently low. Magnetic resonance imaging (MRI) does not have such a disadvantage, and a recent study using this modality demonstrated significant association of insulin resistance and hyperglycemia with increase in LVM and LVM-to-LV end-diastolic volume ratio regardless of age and gender [35, 36]. Compared with studies on T2DM, few studies on T1DM have shown an increase in LV mass [3742] possibly due to the younger age and lower incidence of hypertension in T1DM patients recruited to those studies.

Interstitial fibrosis in diabetic hearts can be assessed by integrated backscatter (myocardial ultrasound reflectivity) in two-dimensional echocardiography [43-45] and by late gadolinium (Gd) enhancement in cardiac MRI [46]. Twodimensional echocardiography indicated an increased integrated backscatter index in the ventricular septum by $55 \%$ and posterior wall by $15 \%$ in diabetic patients as compared with that in non-diabetic controls [45]. Kwong et al. [46] reported that late Gd-enhancement in MRI was present in $28 \%$ of diabetic patients without clinical evidence of myocardial infarction. Which of the two clinical methods is more sensitive for the detection of ventricular fibrosis in diabetic hearts remains unclear.

\section{LV diastolic and systolic dysfunction}

The most frequent echocardiographic finding in asymptomatic T1DM and T2DM patients is LV diastolic dysfunction with normal LVEF. Diastolic dysfunction is detectable in diabetic hearts without hypertrophy [37, 47, 48], indicating that hypertrophy is not a requisite of diabetes-induced ventricular dysfunction. It is difficult to rigorously characterize differences, if any, in ventricular dysfunction between T1DM and T2DM since age and comorbidities in study subjects are not comparable between the studies on T2DM and those on T1DM.

LV diastolic dysfunction evaluated from transmitral LV filling pattern (i.e., abnormal relaxation and/or pseudonormal filling) (Fig. 3) was observed in $47-75 \%$ of asymptomatic normotensive patients with well-controlled T2DM [49-51]. Tissue Doppler imaging (TDI) (Fig. 3) is more sensitive for detection of LV dysfunction than conventional TTE. It enables measurement of myocardial tissue velocities in the longitudinal direction, and the peak early diastolic myocardial velocity $\left(E^{\prime}\right)$ reflects the global LV diastolic function. Kosmala et al. [52] and Di Bonito et al. [53] reported that $E^{\prime}$ was significantly lower in diabetic patients without hypertension than in normal subjects. In a study by Boyer et al. [51], TDI showed LV diastolic dysfunction in $63 \%$ of asymptomatic T2DM patients, while conventional Doppler echocardiography showed the dysfunction in only $46 \%$ of the subjects.

Systolic LV function is also impaired by diabetes, though its incidence appears lower than that of diastolic dysfunction. In several, but not all, studies in the literature, patients with diabetes mellitus had smaller LV fractional shortening (LVFS) and mid-wall shortening than those in
Fig. 3 Examples of Doppler echocardiography in a healthy subject and a T2DM patient. Transmitral flow patterns are shown for a healthy subject (a) and a T2DM patient (b). Peak velocities during early diastole $(E)$ and late diastole (A) are shown. E/A ratios are 2.2 and 0.6 in $\mathbf{a}, \mathbf{b}$, respectively. $\mathbf{c}$, d show tissue Doppler imaging, with positioning of sample volume at the septal mitral annulus, in a healthy subject and a T2DM patient, respectively. The diabetic patient $(\mathbf{d})$ had lower peak velocities during systole $\left(S^{\prime}\right)$ and early diastole $\left(E^{\prime}\right)(7.5$ and $6.0 \mathrm{~cm} / \mathrm{s}$, respectively) than those in the healthy subject (c 8.5 and $15.0 \mathrm{~cm} / \mathrm{s}$, respectively)
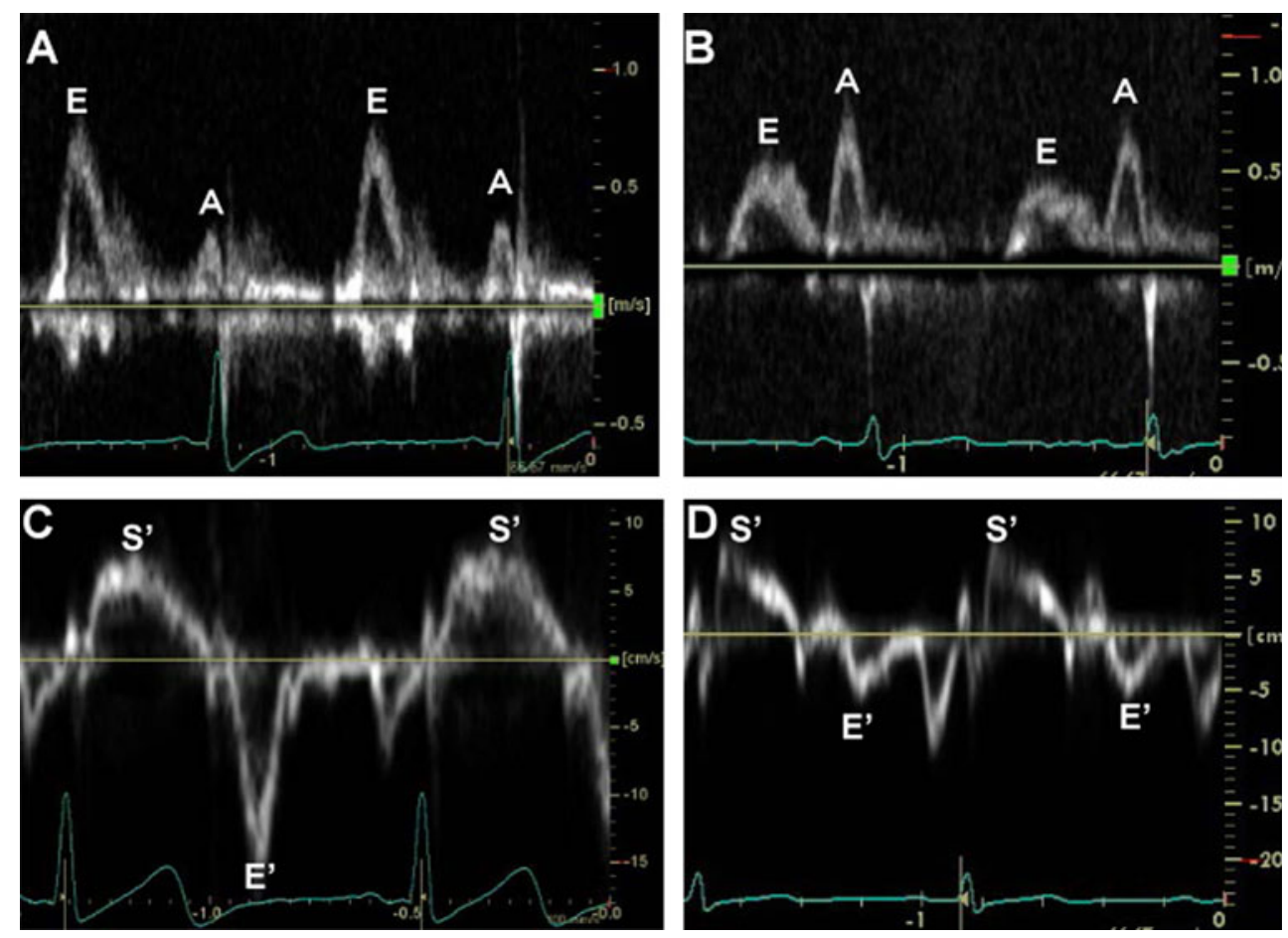
subjects with normal glucose tolerance [30, 31, 35]. The discrepancy in the literature may be attributable to $\mathrm{LV}$ load dependence of LVFS and to relative insensitivity of LVFS in detecting subtle systolic dysfunction. In fact, more sensitive indices of systolic function in TDI and strain rate imaging (SRI) (Fig. 4) consistently indicate subclinical reduction in LV systolic function by diabetes [54-56].

Three studies using TDI $[52,54,55]$ showed that the peak systolic velocity $\left(S^{\prime}\right)$ was $11-20 \%$ lower in normotensive T2DM patients than in non-diabetic subjects, though LVEFs were similar. SRI enables quantitative measurement of regional LV function independent of cardiac rotational motion and tethering effect. Two-dimensional speckle tracking, by which strain rate in all three directions (longitudinal, circumferential and radial) can be determined without angle dependency, has been employed in recent studies for assessment of LV systolic and diastolic dysfunctions in T2DM patients [57, 58]. $\mathrm{Ng}$ et al. [57] reported that longitudinal strain was reduced with preserved radial/circumferential strains in asymptomatic patients with uncomplicated diabetes mellitus. More recently, Ernande et al. [58] showed that both longitudinal and radial strains were reduced after adjustment for blood pressure, age, and body mass index in asymptomatic diabetic patients. Significant LV dysfunction was also detected in T1DM by TDI [38, 40, 41]. Taken together, the findings by TDI and SRI suggest that impaired longitudinal LV shortening, reflecting subendocardial dysfunction, is one of earliest signs in diabetic cardiomyopathy.

Fig. 4 Tissue Doppler-derived strain and strain rate of the left ventricle. a, b show strain and strain rates, respectively, in a normal control. Ss septal peak strain, $S R s$ strain rate in systole, SRe strain rate in early diastole. c shows comparison of LV strain rates in normal controls (white bars, $n=15$ ) and normotensive T2DM patients without coronary artery disease (black bars, $n=15$ ). $* P<0.05$ versus control. (S. Yuda, unpublished data)

\section{Response to stress tests}

Emerging evidence indicates the presence of latent LV dysfunction in diabetic hearts. Ha et al. [47] showed that $S^{\prime}$ and $E^{\prime}$ during an exercise test were significantly lower by $10-15 \%$ in T2DM than in non-diabetic controls, though both $S^{\prime}$ and $E^{\prime}$ were within normal ranges at rest in the two groups. In a study by Jellis et al. [59], who defined abnormal $E^{\prime}$ (septal $E^{\prime}$ ) at rest as $<2 \mathrm{SD}$ of normal for age and abnormal $E^{\prime}$ at peak exercise stress as $<-9.9 \mathrm{~cm} / \mathrm{s}, E^{\prime}$ at stress was abnormally low in $49 \%$ of the T2DM patients with normal $E^{\prime}$ at rest. Palmieri et al. [60] reported that peak exercise stroke volume index and cardiac index were significantly lower in patients with uncomplicated T1DM than in non-diabetic normotensive controls, though LV TDI parameters were comparable in the two groups. Hence, it is likely that prevalence of diabetic cardiomyopathy is much higher than that previously thought in both types of diabetes. Furthermore, latent LV dysfunction caused by diabetes does not appear to be a trivial problem since blunted increase in systolic blood pressure/end-systolic LV volume ratio (SP/ESV) by exercise is associated with poor prognosis [61].

\section{Mechanism of contractile dysfunction of diabetic myocardium}

Different animal models of T1DM (e.g., streptozotocin [STZ]-treated and alloxan-treated animals) and T2DM
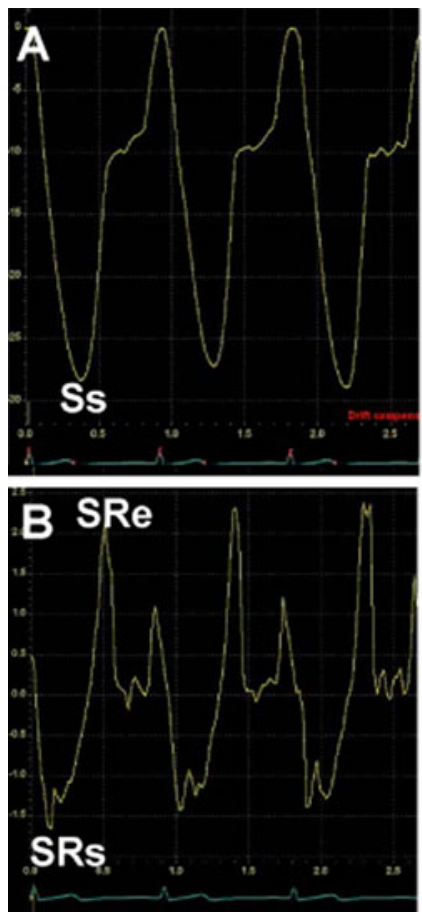

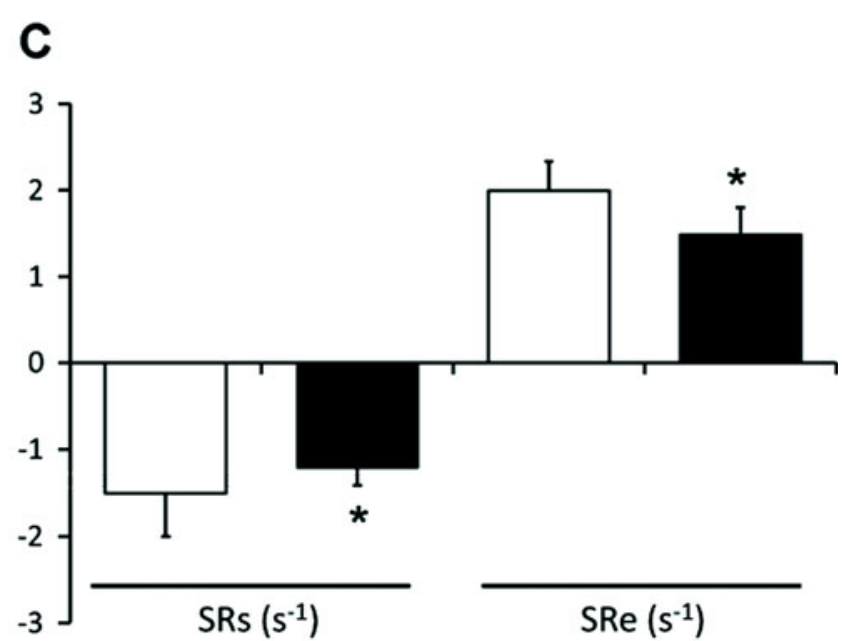


(e.g., Goto-Kakizaki rat, Otsuka-Long-Evans-Fatty rat [OLETF], ob/ob mouse) have been used for investigation of mechanisms by which diabetes impairs contractile function of the heart. In the following sections, we primarily discuss the findings commonly observed in both T1DM and T2DM models, unless otherwise stated.

\section{Impairments in excitation-contraction coupling}

Diabetes significantly modifies action potential, $\mathrm{Ca}^{2+}$ transient and $\mathrm{Ca}^{2+}$ sensitivity of contractile elements in cardiomyocytes [62-66]. Prolongation of action potential duration (APD) and slower decay of $\mathrm{Ca}^{2+}$ transient are consistently observed in diabetic cardiomyocytes. It is notable that such changes in the $\mathrm{Ca}^{2+}$ transient were observed before development of systolic ventricular dysfunction. Peak amplitude of $\mathrm{Ca}^{2+}$ transient was reduced in some [64, 65, 67-69], but not all [70-72], models of diabetes.

As for prolongation of APD, reduction in transient outward $\mathrm{K}^{+}$(Ito) current has been shown in most animal models of diabetes [62, 63, 65, 66, 73], though reduced expression of L-type $\mathrm{Ca}^{2+}$ channel was an additional abnormality in some models $[64,74]$. The prolongation of APD is potentially a compensatory mechanism for preserving $\mathrm{Ca}^{2+}$ influx in cardiomyocytes with down-regulated L-type $\mathrm{Ca}^{2+}$ channel. However, it could lead to untoward outcomes. A study by Sah et al. [75] showed that down-regulation of Ito induces enhanced $\mathrm{Ca}^{2+}$ cycling and activation of calcineurin, leading to interstitial fibrosis and ventricular contractile dysfunction.

Down-regulation of Kv4.2 (one of alpha-subunit subfamilies of the voltage-gated $\mathrm{K}^{+}$channel) expression underlies reduction in Ito current in diabetic hearts. The mechanism of the Kv4.2 down-regulation remains unclear, but inactivation of pyruvate dehydrogenase (PDH) and activation of peroxisome proliferator-activated receptor- $\alpha$ $(\operatorname{PPAR} \alpha)$ may be involved. In the diabetic myocardium, PDH is inhibited by PDH kinase-4 (PDK4) [76-78], and inhibition of PDH by 3-bromopyruvate has been shown to reduce the Ito current in normal cardiomyocytes [79]. Conversely, reduced Ito current in postinfarct remodeling hearts was restored by $4-5 \mathrm{~h}$ treatment with dicholoroacetate or pyruvate [79]. PDK4 is one of enzymes that are upregulated by activation of $\operatorname{PPAR} \alpha[80,81]$, and chronic cardio-specific activation of $\operatorname{PPAR} \alpha$ has been shown to down-regulate protein expression of both $\alpha$-subunit (Kv4.2/ $\mathrm{KCND} 2$ ) and $\beta$-subunit (KChIP2/KCNIP2) of the Ito channel, reducing Ito current density [82]. Hence, it is possible that $\operatorname{PPAR} \alpha$ activation by increased fatty acid uptake is upstream of PDH inhibition in the mechanism of Kv4.2 down-regulation by diabetes.

Slowed decay in $\mathrm{Ca}^{2+}$ transient in diabetic cardiomyocytes is theoretically attributable to reduced rate of $\mathrm{Ca}^{2+}$ removal from the cytosol and/or reduced affinity of troponin $\mathrm{C}$, a major $\mathrm{Ca}^{2+}$ buffer in the cytosol, for $\mathrm{Ca}^{2+}$. As for the effect of diabetes on affinity of troponin $\mathrm{C}$ to $\mathrm{Ca}^{2+}$, a study by Ishikawa et al. [70], the only one to our knowledge, showed that $\mathrm{Ca}^{2+}$ affinity of troponin $\mathrm{C}$ was similar in STZ-induced diabetic and non-diabetic cardiomyocytes. On the other hand, studies using different animal models of diabetes consistently indicated reduction in protein level of sarcoplasmic reticulum $\mathrm{Ca}^{2+}$ ATPase $2 \mathrm{a}$ (SERCA2a) [83], and phospholamban phosphorylation was enhanced in some of the models [63, 64]. In addition, posttranslational modifications of SERCA2a by diabetes were reported by Bidasee et al. [84]; they found nonenzymatic glycosylation of SERCA2a (i.e., formation of advanced glycation end products [AGEs] on SERCA—see section "Remodeling of extracellular matrix" for details) in a model of T1DM, which potentially compromises pump activity of SERCA2a. Another $\mathrm{Ca}^{2+}$ handling protein for $\mathrm{Ca}^{2+}$ efflux, $\mathrm{Na}^{+}-\mathrm{Ca}^{2+}$ exchanger (NCX), is preserved in the diabetic heart [71]. These findings indicate that downregulation of SERCA2a is a primary mechanism of delayed decay in $\mathrm{Ca}^{2+}$ transient. The mechanism by which diabetes reduces SERCA2a expression is unclear, though involvement of nuclear $O$-GlcNAcylation was recently suggested by results of experiments using adenovirus-mediated overexpression of $O$-GlcNac transferase and $O$-GlcNAcase $[85,86]$.

Increased leakage of $\mathrm{Ca}^{2+}$ from the sarcoplasmitc reticulum (SR) has also been reported as an abnormality in diabetic hearts. Belke et al. [68] showed that $\mathrm{Ca}^{2+}$ leak under blockades of NCX and ryanodine receptors (RYRs) was significantly increased in ob/ob mice and that the increase was associated with reduced expression of FKBP12.6, a regulatory factor of RYRs. In a study that determined local SR $\mathrm{Ca}^{2+}$ release as " $\mathrm{Ca}^{2+}$ sparks" by use of a fluorescent $\mathrm{Ca}^{2+}$ probe, frequency of the $\mathrm{Ca}^{2+}$ sparks was increased by $60 \%$ in association with reduction of both RYR2 and FKBP12.6 by $50 \%$ in the myocardium of rats with STZ-induced diabetes [87]. Interestingly, the increase in local $\mathrm{Ca}^{2+}$ sparks and down-regulation of RYR2 and FKBP12.6 were attenuated by candesartan, indicating involvement of $\mathrm{AT}_{1}$ receptor activation [69]. The $\mathrm{Ca}^{2+}$ leak via dysfunctional $\mathrm{RYR}$ and reduced $\mathrm{Ca}^{2+}$ uptake by SERCA2a appear to be responsible for significant reduction in $\mathrm{SR} \mathrm{Ca}^{2+}$ store by diabetes [67].

Change in $\mathrm{Ca}^{2+}$ sensitivity of contractile proteins by diabetes is controversial. Data are contradictory (i.e., decrease vs. increase in $\mathrm{Ca}^{2+}$ sensitivity) even in the same T1DM model (STZ-induced diabetes) [88, 89]. In a study using cardiomyoytes from T2DM patients undergoing coronary artery bypass surgery, significant reduction of $\mathrm{Ca}^{2+}$ sensitivity was observed [90]. There is no clear explanation for the contradictory results. 
Metabolic derangements

Turnover of ATP (up to $35 \mathrm{~kg} /$ day) is many times of its pool, and extraction of energy from substrates is not very large $(\sim 25 \%)$ in the myocardium [91-93]. Thus, a small reduction in the efficiency of ATP synthesis could significantly compromise cellular functions, including contraction and relaxation. Diabetes reduces the efficiency of energy production by increase in fatty acid uptake and suppression of glucose oxidation. Fatty acid oxidation is augmented not only by elevation of plasma level of fatty acid but also by activation of PPAR $\alpha$. PPAR $\alpha$ is activated by intracellular fatty acids and up-regulates multiple enzymes relevant to fatty acid metabolism [94, 95]. PPAR $\alpha$ contributes also to suppression of glucose oxidation by up-regulation of PDK4 transcription [96]. Most of the cytosolic long-chain acyl-CoAs are used for $\beta$-oxidation in mitochondria, and approximately $80 \%$ of acetyl-CoA in the heart of a model of T2DM, db/db mouse, was found to be fatty acid-derived both when perfused with low glucose/ low fatty acid buffer and when perfused with high glucose/ high fatty acid buffer [97].

Glucose oxidation is inhibited at multiple steps in diabetic hearts. Uptake of glucose is impaired in diabetic hearts by down-regulated expression of GLUT4/GLUT1 and by blunted sarcolemmal translocation of GLUT4 in response to insulin [98, 99]. Impaired tyrosine phosphorylation of the insulin receptor and insulin receptor substrates and blunted activation of PI3K-Akt signaling are involved in the deficient response of diabetic hearts to insulin. In addition, activities of hexokinase, phosphofructokinase, and PDH are inhibited by long-chain acyl-CoA, citrate, and PDK4 in the diabetic myocardium [96, 100, 101].

Mitochondrial dysfunction is also responsible for reduced efficiency in energy production in the diabetic heart as recently reviewed by Bugger and Able [102]. Production of cytotoxic reactive oxygen species (ROS) was augmented in mitochondria in different types of diabetes. Increased fatty acid oxidation, which has higher oxygen cost than glucose, and increased activity of uncoupling proteins (UCPs) in mitochondria appear to underlie the augmented ROS production. ROS can directly activate UCP3 and further reduce efficiency of ATP production in mitochondria [103, 104].

Extra-mitochondrial ROS level is also increased in a model of T2DM (obese Zucker rat). In this model, increased metabolic flux to the pentose phosphate pathway augments generation of Nox-derived ROS by the elevation of NADPH level due to up-regulated activity of glucose-6phophate dehydrogenase (G6PD) [105]. Protein kinase C (PKC) contributes to the up-regulation of G6PD. However, such up-regulation of G6PD activity in the myocardium was not detected in a model of T1DM (STZ-induced diabetes) [106].

An important question is whether supply of ATP is indeed insufficient for its demand in diabetic cardiomyocytes. A clue to the answer to this question is change in the phosphocreatine (PCr)/ATP ratio. Reduction of PCr/ATP ratio indicates suppressed ATP production and/or suppressed production of PCr from ATP by the creatine kinase (CK) system. Determination of PCr and ATP in the human myocardium by magnetic resonance spectroscopy (MRS) showed that the PCr/ATP ratio is significantly reduced by diabetes and that the ratio negatively correlates with plasma free fatty acid level or live triglyceride level [107, 108]. These observations support the notion that supply of ATP in response to intracellular demand is compromised in diabetic hearts. It is notable that the cardiac metabolic derangement indicated by PCr/ATP precedes ventricular dysfunction detectable at rest in the diabetic heart but possibly underlies the dysfunction unmasked by stress tests (section "Response to stress tests").

\section{Remodeling of extracellular matrix}

Distinguishing from enzymatic glycosylation of proteins, non-enzymatic formation of stable glycosylation product by Amadori rearrangement (Amadori product) is called glycation. Glycated proteins undergo a series of chemical rearrangements to form complex compounds with crosslinks, which are referred to as advanced glycation end products (AGEs). AGEs have been shown to be increased in plasma by hyperglycemia, aging, and renal failure [16, 109-111]. Accumulation of AGE in collagen was associated with reduced collagen turnover, indicating the possibility that cross-linking of collagen makes collagen resistant to hydrolytic turnover [112]. Such AGE-mediated cross-linking of collagen is thought to be responsible for increased stiffness of arteries and the myocardium. In fact, AGE in the myocardium increases in T1DM and T2DM, and positive correlations of serum level of AGEs with ventricular isovolumetric relaxation time, arterial stiffness, and carotid intimal thickness have been shown in diabetics [109, 110, 113]. Furthermore, treatment with an inhibitor of AGE formation (aminoguanidine) prevented ventricular dysfunction in diabetic rats [114, 115]. Treatment with alagebrium (ALT-711), an "AGE cross-link breaker", restored the $\mathrm{LV}$ function and reduced myocardial collagens in a canine model of diabetes [116], and its beneficial effect on LV diastolic function was suggested in heart failure patients with preserved ejection fraction [117].

Fibrosis in the cardiac interstitium and perivascular space in diabetic patients is reproducible in animal models at the late stage of diabetes. Contribution of the AT1 receptor to fibrosis is supported in the models of diabetes 
by three lines of evidence. AT1 receptor activity was upregulated in diabetic hearts $[118,119]$, and this receptor is coupled with transforming growth factor- $\beta 1$ (TGF- $\beta 1$ ) signaling, which stimulates collagen production $[120,121]$. Inhibition of AT1 receptor activity by AT1 receptor blockers (ARBs) or angiotensin converting enzyme (ACE) inhibitors ameliorated interstitial fibrosis and significantly improved LV function [120]. It should be noted that extent of interstitial fibrosis and that of glycation of proteins do not necessarily change in parallel [89].

Abnormalities in microvasculature

"Microangiopathy" has been demonstrated in the myocardium of diabetic patients, and it was reproducible in a rat model of diabetes [12, 14, 21, 22, 122, 123]. Thickening of the capillary basement membrane, medial thickening of the arteriole, and perivascular fibrosis were observed in autopsy samples of the ventricular myocardium by conventional histology [12, 14, 21, 22]. Visualization of three-dimensional morphology of microvessels by use of the microfill technique showed microaneurysms, spasm, and spiral deformation of microvessels in the myocardium of T1DM and T2DM [122]. These vascular changes are reproducible in rat hearts by STZinduced diabetes and hypertension [123].

In addition to morphology, density of the microvessels is modified in the heart by diabetes. Yoon et al. [124] showed that expression of vascular endothelial cell growth factor (VEGF) in the heart is down-regulated by diabetes and that the down-regulation is closely associated with reduction in capillary density, apoptosis of endothelial cells and interstitial fibrosis. Since insulin induces VEGF expression via PI3K-Akt signaling [125], impairment of this signaling in the diabetic heart may be responsible for the down-regulation of VEGF expression. Furthermore, restoration of VEGF by intramyocardial injection of plasmid DNA encoding VEGF prevented loss of capillaries in diabetic mice [124]. Unfortunately, data on VEGF expression in the human diabetic myocardium are contradictory in the literature [126-128]. VEGF mRNA level in ventricular biopsy samples from diabetic patients was reportedly reduced [126], not changed in the non-ischemic area and reduced in the ischemic area [127] or increased [128] as compared with non-diabetic patients. Difference between clinical backgrounds in study subjects might be involved in the contradictory results in human studies.

Reduction in coronary blood flow reserve (CFR) by diabetes has been demonstrated in both clinical and experimental studies [129-131]. In diabetic patients, CFR was inversely correlated with an index of LV relaxation (time from R-wave on the electrocardiogram to the onset of relaxation) [131]. In a rat model of obese T2DM (OLETF), CFR was reduced and inversely correlated with wall-to- lumen ratio of arterioles $(<100 \mu \mathrm{m}$ in diameter) and with extent of perivascular fibrosis [129]. Activation of the receptor for AGE (RAGE) in the endothelium by AGE inhibits production of nitric oxide (NO) and up-regulates expression of cell adhesion molecules [16]. Use of an AGE cross-link breaker, alagebrium, significantly improved flow-mediated dilatation in hypertensive patients [132]. Taken together, blunted NO production, AGE-mediated stiffening of coronary media, reduced angiogenesis, and perivascular fibrosis are possibly responsible for the reduction of CFR in diabetic hearts.

\section{Myocardial tolerance against ischemia/reperfusion- induced necrosis}

Changes in myocardial susceptibility to infarction by diabetes

Although clinical studies indicate enlargement of infarct size by diabetes in patients treated with reperfusion therapy $[27,28]$, animal studies have shown different diabetesinduced changes in infarct size as summarized in Table 1 [119, 133-181]. There were multiple differences in the experimental preparations and protocols, and a single factor cannot explain the discrepancy in effects of diabetes on infarct size. However, duration of the diabetic state and plasma level of insulin (i.e., T1DM vs. T2DM) appear to influence myocardial tolerance against infarction. In a study by Ravingerová et al. [147], infarct size after 30-min ischemia was smaller in diabetic rat hearts at 1 week after STZ injection than in controls, but this infarct size limitation was not detected 8 weeks later. Two other studies have also shown that increased resistance of diabetic hearts to ischemia/reperfusion injury at the early phase of diabetes later disappeared [149, 150]. However, enlargement of infarct size as early as 8 days after STZ injection was also reported [134, 135, 137], indicating involvement of a factor other than diabetes duration in infarct size change. As for insulin level, diabetic models with obesity and hyperinsulinemia [119, 140, 142-144], except for a few reports [153, 165], showed larger infarct size than that in non-diabetic controls.

Diabetes-induced defects in intracellular protective signaling

Diabetes is one of the pathological states that impair intracellular signaling for cardiomyocyte protection. Except for a few studies, previous studies showed that cardioprotection achieved by ischemic preconditioning (IPC) or ischemic postconditioning (IPost) is lost or required extra-cycles of "conditioning" in experimental 
Table 1 Effects of diabetes and hyperglycemia on infarct size
GK rat Goto-Kakizaki rat, OLETF rat Otsuka Long-EvansTokushima Fatty rat, STZ streptozotocin, WOKW rat Wistar-Ottawa-Karlsburg W rat

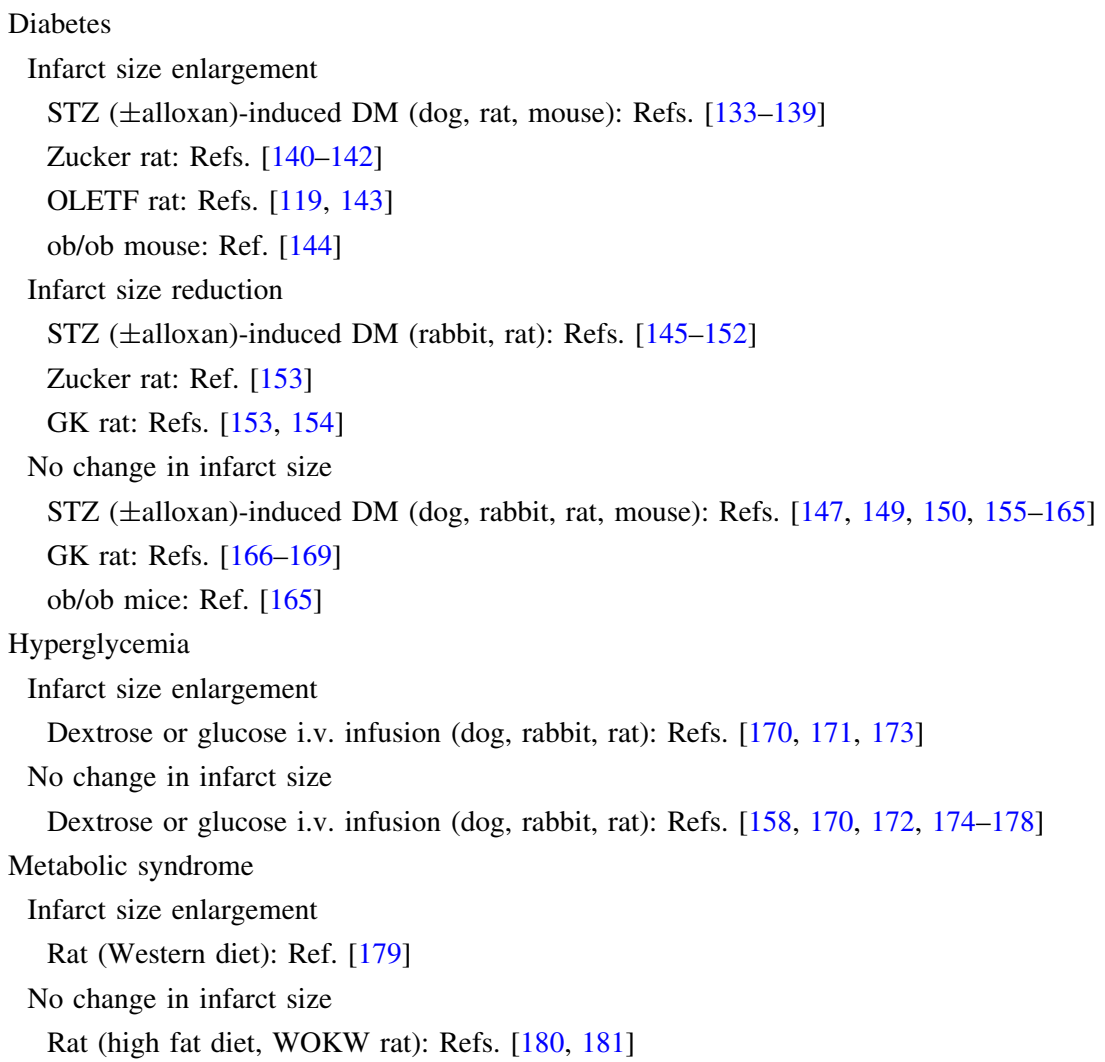

diabetes (Table 2) $[141,144,145,151,153,157,159$, 160, 163, 165, 166, 182]. Mimetics of IPC and IPost (diazoxide, erythropoietin, [D-Ala ${ }^{2}$, D-Leu ${ }^{5}$ ]-enkephalin acetate [DADLE] and isoflurane) were also ineffective in limitation of infarct size in diabetic hearts [119, 141, 143, 158, 161-163, 169], confirming impairment of protective signaling by diabetes.

Like animal models of diabetes, diabetic human hearts have defects in cytoprotective mechanisms. Ishihara et al. [183] showed that preinfarct angina pectoris, a clinical counterpart of IPC, reduced CK release and improved recovery of cardiac function and in-hospital survival after acute myocardial infarction in non-diabetic patients but not in diabetics. Impairment of IPC in human diabetes was also shown during angioplasty [184] and during a treadmill exercise test [185] by use of electrocardiographic severity of ischemia as an endpoint. Direct evidence for diabetesinduced loss of IPC protection in human hearts was provided by an in vitro experiment using atrial trabeculae obtained at open heart surgery. IPC failed to suppress CK release and contractile dysfunction after hypoxia/reoxygenation in vitro in atrial trabeculae from diabetic patients [186, 187].

Multiple defects in cytoprotective signal pathways have been indicated in diabetic hearts. Our recent studies have shown that Jak2, being upstream of PI3K-Akt signaling, is inhibited by enhanced calcineurin activity and that phosphorylation of GSK-3 $\beta$ by ERK is lost by an endoplasmic reticulum stress-dependent mechanism in a rat model of T2DM [119, 143]. Furthermore, protein level of active GSK-3 $\beta$, a pro-necrotic and pro-apoptotic kinase, was increased in mitochondria, leading to increase in susceptibility of mitochondrial permeability transition in response to calcium overload [143]. On the other hand, a protective mechanism downstream of GSK-3 $\beta$ phosphorylation appears to be intact in diabetic hearts, since direct inhibitors of GSK-3 $\beta$ limit infarct size similarly in diabetic and non-diabetic animals [119, 143, 161, 162, 182].

There is limited information on whether glycemia control repairs defects in protective signaling in diabetic hearts. Acute hyperglycemia induced by dextrose infusion impaired infarct size limitation by IPC, a mitochondrial $\mathrm{K}_{\mathrm{ATP}}$ channel opener and anesthetic agents [158, 170, 172, 174-178], indicating a primary role of hyperglycemia in impairment of protective signaling. Recently, Przyklenk et al. [165] reported that the cardioprotective effect of IPost was re-established in STZ-induced diabetic mice by pancreas islet cell transplantation. Transplantation of islet cells in diabetic mice normalized blood glucose level and also ERK signaling activated by IPost. Since dyslipidemia reportedly attenuates the infarct size-limiting effect of IPC [188-190], restoration of the protective effect of IPost in 
Table 2 Effects of diabetes and hyperglycemia on cardioprotection afforded by pre- and postconditioning and their mimetics
$P C$ preconditioning, PostC postconditioning, $G S K-3 \beta$ glycogen synthase kinase- $3 \beta$, $K_{A T P}$ channel ATP-sensitive potassium channel, $P D E 3$ phosphodiesterase $3, P P A R-\alpha$ peroxisome proliferatoractivated receptor- $\alpha, S W O P$ second window of protection

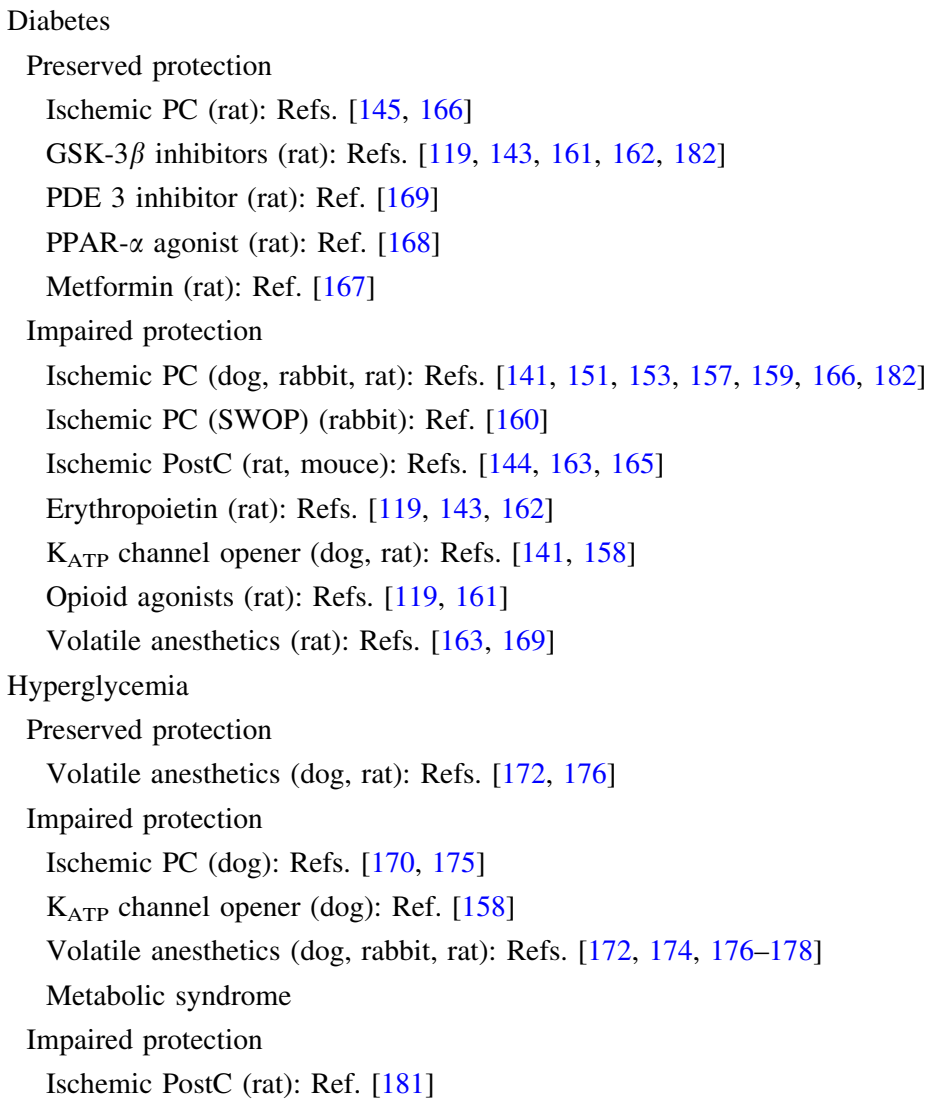

the diabetic heart by islet cell transplantation could have been a result of normalization of both plasma glucose and lipid profile. Nevertheless, circumstantial evidence to date supports the notion that normalization of the metabolic profile restores protective signaling mechanisms in the diabetic heart.

\section{Clinical diagnosis of diabetic cardiomyopathy}

Currently, the best approach to the diagnosis of diabetic cardiomyopathy is detection of functional and structural changes in the LV and exclusion of other heart diseases being responsible for the changes in a diabetic patient. Diagnostic clues of diabetic cardiomyopathy are listed in Table 3, TDI and SRI being the most practical for detection of diabetic cardiomyopathy on a daily basis.

Left ventricular diastolic dysfunction detectable by TDI (and possible also by SRI) at exercise stress may be the earliest sign of diabetes-induced LV dysfunction as discussed in section "Clinical phenotype of diabetic cardiomyopathy". Thus, normal echocardiographic findings at rest do not exclude presence of diabetic cardiomyopathy. Studies to date support the notion that diastolic dysfunction
Table 3 Diagnostic clues of diabetic cardiomyopathy

CMR cardiac magnetic resonance imaging, $2 D$ two dimensional, $L V$ left ventricular, $M R S$ magnetic resonance spectroscopy, SRI strain/strain rate imaging, TDI tissue Doppler imaging

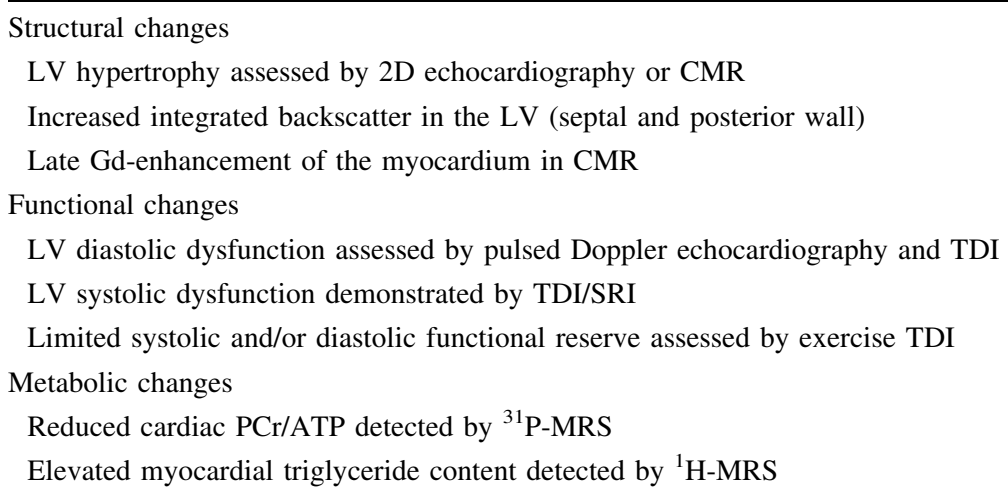


develops earlier than systolic dysfunction in diabetic hearts. However, Ernande et al. [191] recently reported that systolic longitudinal strain rate was abnormal in $28 \%$ of diabetic patients with normal diastolic function and in $35 \%$ of those with diastolic dysfunction. Assessment of interstitial fibrosis by integrated backscatter or Gd-enhancement of cardiac MRI is possible [43-46], but its diagnostic value has not yet been established.

A promising novel approach to diagnosis of diabetic myopathy is characterization of metabolic changes in the myocardium by ${ }^{31} \mathrm{P}-\mathrm{MRS}$ and by ${ }^{1} \mathrm{H}-\mathrm{MRS}$. As discussed in section "Metabolic derangements", the PCr/ATP ratio, an index of energy charge, is reduced in the myocardium of diabetic patients compared with that in control subjects. Recent studies using ${ }^{1} \mathrm{H}$-MRS have demonstrated that increase in myocardial triglyceride content (i.e., myocardial steatosis) was associated with LV diastolic dysfunction in diabetic patients [192, 193]. Furthermore, Ng et al. [194] showed that myocardial steatosis was independently correlated with LV longitudinal strain and with systolic and diastolic strain rates determined by two-dimensional speckle tracking imaging in patients with uncomplicated diabetes mellitus. The possibility that myocardial steatosis is a specific marker of the diabetic cardiomyopathy warrants further investigation.

\section{Prevention and treatment of diabetic cardiomyopathy}

Prevention of diabetic cardiomyopathy

Although high prevalence of subclinical myocardial dysfunction has been reported in the early stage of T1DM, clinically relevant heart failure is relatively rare in this type of diabetes. In an observational study, 462 T1DM patients without a previous history of heart disease were followed up, and it found that only 17 patients (3.7\%) developed heart failure during a 12-year follow-up period [195]. The patients who developed heart failure in this cohort were older and had longer diabetes durations ( $35 \pm 9$ years), higher blood pressure, and higher prevalence of albuminuria and retinopathy than those in patients without heart failure. In contrast, heart failure develops more frequently in patients with T2DM $[4,5]$, which is frequently associated with other co-morbidities, such as hypertension, predisposing to heart failure. Hence, it is unlikely that glycemic control alone is sufficient for the prevention of diabetic cardiomyopathy.

A number of clinical trials have been conducted to evaluate the impact of glycemic control on the prevention of cardiovascular events in T2DM. However, end-points in the studies were atherosclerotic cardiovascular events and death, leaving non-ischemic heart failure not specifically determined. A recently published meta-analysis including a total of 27,049 subjects in the UKPDS 33 (UK Prospective Diabetes Study 33), ACCORD, ADVANCE, and VADT trials showed that mortality was not affected by intensive glycemic control, with hazard risks of 1.10 for cardiovascular death (95\% confidence interval [CI]; 0.84-1.42) and 1.04 for all-cause death (95\% CI: 0.90-1.20) [196]. These findings may appear to argue against the notion that tight glycemic control is beneficial for prevention of diabetic cardiomyopathy. However, the results do not preclude the possibility that intensive glycemic control commenced at an earlier stage of diabetes together with control of other risk factors prevents heart failure in diabetic patients. This speculation is supported by a few lines, at least, of evidence. First, clinical studies using TDI showed that glycemic control improved LV diastolic function in T2DM [197, 198]. Second, the Steno-2 trial [199] showed that simultaneous control of glycemia, hypertension, and dyslipidemia significantly reduced cardiovascular events and mortality in T2DM patients. Third, a recent meta-analysis of clinical trials on hypertension indicates that diabetes increases incidence of heart failure by more than fourfold in hypertensive patients [8].

Whether incidence and/or outcome of heart failure differ depending on the type of hypoglycemic agent selected for hyperglycemia control remains unclear. This issue has not been addressed by a prospective randomized clinical trial. In observational cohort studies and retrospective analyses of registered patients, use of metformin is associated with low incidence of heart failure compared with other glycemia control regimens [200]. Furthermore, clinical outcomes in diabetic patients with heart failure were better in groups treated with metformin [201, 202]. Aguilar et al. [202] matched metformin-treated and metformin-untreated groups of diabetic patients with heart failure and showed that mortality was lower in the metformin-treated group.

In contrast with metformin, thiazolidinedione (TZD) has been shown to increase incidence of "heart failure" in diabetes compared with sulfonylurea. Unfortunately, it is not clear whether the increase in "heart failure" by TZD indeed reflects worsening of LV function or just retention of fluids [203-206]. In fact, recent studies have suggested a favorable effect of TZD on cardiac function [207, 208]. Six months of treatment with pioglitazone improved diastolic function assessed by Doppler echocardiography in hypertensive patients in proportion to the amelioration of insulin resistance [207]. The same duration of treatment with pioglitazone was also reported to improve diastolic function and LV compliance assessed by MRI in uncomplicated T2DM patients [208]. It is notable, however, that improvement in the function could not be explained by treatment-related myocardial metabolic change assessed by positron emission tomography and MRS. Nevertheless, 
prospective clinical trials are necessary to clarify efficacies of hypoglycemic agents in prevention of diabetic cardiomyopathy.

Management of heart failure in diabetic patients

Optimal treatment of heart failure in diabetic patients has not been specifically addressed, and relevant information is limited to effects of diabetes on the efficacy of a heart failure therapy in subgroup analyses of trials. In earlier studies, ACE inhibitor was suggested to be similarly effective in diabetic and non-diabetic patients with heart failure with reduced LVEF $[209,210]$ and that was the case for ARB as well [10]. In contrast, the benefit of a $\beta$-blocker on mortality may be attenuated in diabetic patients, especially in elderly patients $[211,212]$. Under the standard treatment with these agents, prognosis of heart failure patients with diabetes is worse than that of heart failure patients without diabetes irrespective of LVEF levels [10, 213]. Heart failure with preserved LVEF is a primary phenotype in diabetes, and therapy to improve prognosis of this type of heart failure in general is still under intensive investigation [214].

\section{Perspectives}

Accumulating evidence obtained by novel imaging techniques (i.e., TDI, SRI, MRS) indicates that these techniques for functional and metabolic analyses of human hearts will make it possible to formulate clinical parameters for diagnosis of diabetic cardiomyopathy. Such diagnostic criteria would facilitate the design of prospective studies to search for optimal therapy for prevention and treatment of this cardiomyopathy. Numerous questions regarding pathogenesis of diabetic cardiomyopathy still remain, but molecular mechanisms of down-regulation of SERCA2a, mitochondrial dysfunction, and defects in cytoprotective signaling appear particularly important issues for designing novel therapies for restoration of contractile function and prevention of progressive heart failure. Novel therapy is in urgent need since even mild diastolic dysfunction in diabetic hearts has been shown to be associated with more than a threefold increase in all-cause mortality [215].

Acknowledgments This work was supported by Japanese Society for the Promotion of Science Grants-in-Aid for Scientific Research (23591085), Tokyo, Japan.

Conflict of interest Dr. Takayuki Miki has received research funding from Daiichi-Sankyo, Japan, Eisai, Japan, and Pfizer, Japan. Drs. Satoshi Yuda and Hidemichi Kouzu have no conflicts of interest or financial ties to disclose. Dr. Tetsuji Miura has received research funding from Takeda Pharmaceuticals, Japan, Novartis, Japan, Chugai Pharmaceutical, Japan, and Astellas Pharma, Japan.

Open Access This article is distributed under the terms of the Creative Commons Attribution License which permits any use, distribution, and reproduction in any medium, provided the original author(s) and the source are credited.

\section{References}

1. Danaei G, Finucane MM, Lu Y, Singh GM, Cowan MJ, Paciorek CJ, Lin JK, Farzadfar F, Khang YH, Stevens GA, Rao M, Ali MK, Riley LM, Robinson CA, Ezzati M, Global Burden of Metabolic Risk Factors of Chronic Diseases Collaborating Group (Blood Glucose) (2011) National, regional, and global trends in fasting plasma glucose and diabetes prevalence since 1980: systematic analysis of health examination surveys and epidemiological studies with 370 country-years and 2.7 million participants. Lancet 378:31-40

2. Sobel BE (2007) Optimizing cardiovascular outcomes in diabetes mellitus. Am J Med 120(Suppl 2):S3-S11

3. Gaede P, Pedersen O (2004) Intensive integrated therapy of type 2 diabetes: implications for long-term prognosis. Diabetes 53(Suppl 3):S39-S47

4. From AM, Leibson CL, Bursi F, Redfield MM, Weston SA, Jacobsen SJ, Rodeheffer RJ, Roger VL (2006) Diabetes in heart failure: prevalence and impact on outcome in the population. Am J Med 119:591-599

5. Bell DS (2003) Heart failure: the frequent, forgotten, and often fatal complication of diabetes. Diabetes Care 26:2433-2441

6. Carrabba N, Valenti R, Parodi G, Santoro GM, Antoniucci D (2004) Left ventricular remodeling and heart failure in diabetic patients treated with primary angioplasty for acute myocardial infarction. Circulation 110:1974-1979

7. Lewis EF, Velazquez EJ, Solomon SD, Hellkamp AS, McMurray JJ, Mathias J, Rouleau JL, Maggioni AP, Swedberg K, Kober L, White H, Dalby AJ, Francis GS, Zannad F, Califf RM, Pfeffer MA (2008) Predictors of the first heart failure hospitalization in patients who are stable survivors of myocardial infarction complicated by pulmonary congestion and/or left ventricular dysfunction: a VALIANT study. Eur Heart J 29: 748-756

8. Tocci G, Sciarretta S, Volpe M (2008) Development of heart failure in recent hypertension trials. J Hypertens 26:1477-1486

9. Du X, Ninomiya T, de Galan B, Abadir E, Chalmers J, Pillai A, Woodward M, Cooper M, Harrap S, Hamet P, Poulter N, Lip GY, Patel A, ADVANCE Collaborative Group (2009) Risks of cardiovascular events and effects of routine blood pressure lowering among patients with type 2 diabetes and atrial fibrillation: results of the ADVANCE study. Eur Heart J 30:1128-1135

10. MacDonald MR, Petrie MC, Varyani F, Ostergren J, Michelson EL, Young JB, Solomon SD, Granger CB, Swedberg K, Yusuf S, Pfeffer MA, McMurray JJ, CHARM Investigators (2008) Impact of diabetes on outcomes in patients with low and preserved ejection fraction heart failure: an analysis of the candesartan in heart failure: Assessment of Reduction in Mortality and morbidity (CHARM) programme. Eur Heart J 29:1377-1385

11. Shah AM, Uno H, Køber L, Velazquez EJ, Maggioni AP, MacDonald MR, Petrie MC, McMurray JJ, Califf RM, Pfeffer MA, Solomon SD (2010) The inter-relationship of diabetes and left ventricular systolic function on outcome after high-risk myocardial infarction. Eur J Heart Fail 12:1229-1237 
12. Rubler S, Dlugash J, Yuceoglu YZ, Kumral T, Branwood AW, Grishman A (1972) New type of cardiomyopathy associated with diabetic glomerulosclerosis. Am J Cardiol 30:595-602

13. Aneja A, Tang WH, Bansilal S, Garcia MJ, Farkouh ME (2008) Diabetic cardiomyopathy: insights into pathogenesis, diagnostic challenges, and therapeutic options. Am J Med 121:748-757

14. Factor SM, Minase T, Sonnenblick EH (1980) Clinical and morphological features of human hypertensive-diabetic cardiomyopathy. Am Heart J 99:446-458

15. Van Hoeven KH, Factor SM (1990) A comparison of the pathological spectrum of hypertensive, diabetic, and hypertensive-diabetic heart disease. Circulation 82:848-855

16. Goldin A, Beckman JA, Schmidt AM, Creager MA (2006) Advanced glycation end products. Sparking the development of diabetic vascular injury. Circulation 114:597-605

17. Schalkwijk CG, Baidoshvili A, Stehouwer CD, van Hinsbergh VW, Niessen HW (2004) Increased accumulation of the glycoxidation product Nepsilon-(carboxymethyl)lysine in hearts of diabetic patients: generation and characterisation of a monoclonal anti-CML antibody. Biochim Biophys Acta 1636: 82-89

18. van Heerebeek L, Hamdani N, Handoko ML, Falcao-Pires I, Musters RJ, Kupreishvili K, Ijsselmuiden AJ, Schalkwijk CG, Bronzwaer JG, Diamant M, Borbély A, van der Velden J, Stienen GJ, Laarman GJ, Niessen HW, Paulus WJ (2008) Diastolic stiffness of the failing diabetic heart: importance of fibrosis, advanced glycation end products, and myocyte resting tension. Circulation 117:43-51

19. Falcão-Pires I, Hamdani N, Borbély A, Gavina C, Schalkwijk CG, van der Velden J, van Heerebeek L, Stienen GJ, Niessen HW, Leite-Moreira AF, Paulus WJ (2011) Diabetes mellitus worsens diastolic left ventricular dysfunction in aortic stenosis through altered myocardial structure and cardiomyocyte stiffness. Circulation 124:1151-1159

20. Fischer VW, Barner HB, Larose LS (1984) Pathomorphologic aspects of muscular tissue in diabetes mellitus. Human Pathol 15:1127-1136

21. Yarom R, Zirkin H, Stämmler G, Rose G (1992) Human coronary microvessels in diabetes and ischaemia. Morphometric study of autopsy material. J Pathol 166:265

22. Kawaguchi M, Techigawara M, Ishihata T, Asakura T, Saito F, Maehara K, Maruyama Y (1997) A comparison of ultrastructural changes in endomyocardial biopsy specimens obtained from patients with diabetes mellitus with and without hypertension. Heart Vessels 12:267-271

23. Sakata S, Lebeche D, Sakata Y, Sakata N, Chemaly ER, Liang L, Nakajima-Takenaka C, Tsuji T, Konishi N, del Monte F, Hajjar RJ, Takaki M (2007) Transcoronary gene transfer of SERCA2a increases coronary blood flow and decreases cardiomyocyte size in a type 2 diabetic rat model. Am J Physiol Heart Circ Physiol 292:H1204-H1207

24. Vahtola E, Louhelainen M, Merasto S, Martonen E, Penttinen S, Aahos I, Kytö V, Virtanen I, Mervaala E (2008) Forkhead class $\mathrm{O}$ transcription factor $3 \mathrm{a}$ activation and Sirtuin1 overexpression in the hypertrophied myocardium of the diabetic Goto-Kakizaki rat. J Hypertens 26:334-344

25. Li J, Zhu H, Shen E, Wan L, Arnold JMO, Peng T (2010) Deficiency of Rac1 blocks NADH oxidase activation, inhibits endoplasmic reticulum stress, and reduces myocardial remodeling in a mouse model of type 1 diabetes. Diabetes 59: 2033-2042

26. Basu R, Oudit GY, Wang X, Zhang L, Ussher JR, Lopaschuk GD, Kassiri Z (2009) Type 1 diabetic cardiomyopathy in the Akita (Ins2WT/C96Y) mouse model is characterized by lipotoxicity and diastolic dysfunction with preserved systolic function. Am J Physiol Heart Circ Physiol 297:H2096-H2108
27. Marso SP, Miller T, Rutherford BD, Gibbons RJ, Qureshi M, Kalynych A, Turco M, Schultheiss HP, Mehran R, Krucoff MW, Lansky AJ, Stone GW (2007) Comparison of myocardial reperfusion in patients undergoing percutaneous coronary intervention in ST-segment elevation acute myocardial infarction with versus without diabetes mellitus (from the EMERALD Trial). Am J Cardiol 100:206-210

28. Algeria JR, Miller TD, Gibbons RJ, Yi QL, Yusuf S, Collaborative Organization of RheothRx Evaluation (CORE) Trial Investigators (2007) Infarct size, ejection fraction, and mortality in diabetic patients with acute myocardial infarction treated with thrombolytic therapy. Am Heart J 154:743-750

29. Galderisi M, Anderson KM, Wilson PF, Levy D (1991) Echocardiographic evidence for the existence of a distinct diabetic cardiomyopathy (The Framingham Heart Study). Am J Cardiol 68:85-89

30. Devereux RB, Roman MJ, Paranicas M, O'Grady MJ, Lee ET, Welty TK, Fabsitz RR, Robbins D, Rhoades ER, Howard BV (2000) Impact of diabetes on cardiac structure and function: the Strong Heart Study. Circulation 101:2271-2276

31. Bella JN, Devereux RB, Roman MJ, Palmieri V, Liu JE, Paranicas M, Welty TK, Lee ET, Fabsitz RR, Howard BV (2001) Separate and joint effects of systemic hypertension and diabetes mellitus on left ventricular structure and function in American Indians (the Strong Heart Study). Am J Cardiol 87:1260-1265

32. Tenenbaum A, Fisman EZ, Schwammenthal E, Adler Y, Benderly M, Motro M, Shemesh J (2003) Increased prevalence of left ventricular hypertrophy in hypertensive women with type 2 diabetes mellitus. Cardiovasc Diabetol 2:14

33. Rutter MK, Parise H, Benjamin EJ, Levy D, Larson MG, Meigs JB, Nesto RW, Wilson PW, Vasan RS (2003) Impact of glucose intolerance and insulin resistance on cardiac structure and function: sex-related differences in the Framingham Heart Study. Circulation 107:448-454

34. Bertoni AG, Goff DC Jr, D'Agostino RB Jr, Liu K, Hundley WG, Lima JA, Polak JF, Saad MF, Szklo M, Tracy RP, Siscovick DS (2006) Diabetic cardiomyopathy and subclinical cardiovascular disease: the Multi-Ethnic Study of Atherosclerosis (MESA). Diabetes Care 29:588-594

35. Heckbert SR, Post W, Pearson GD, Arnett DK, Gomes AS, Jerosch-Herold M, Hundley WG, Lima JA, Bluemke DA (2006) Traditional cardiovascular risk factors in relation to left ventricular mass, volume, and systolic function by cardiac magnetic resonance imaging: the Multiethnic Study of Atherosclerosis. J Am Coll Cardiol 48:2285-2292

36. Velagaleti RS, Gona P, Chuang ML, Salton CJ, Fox CS, Blease SJ, Yeon SB, Manning WJ, O'Donnell CJ (2010) Relations of insulin resistance and glycemic abnormalities to cardiovascular magnestic resonance measures of cardiac structure and function. The Framingham Heart Study. Circ Cardiovasc Imaging 3: 257-263

37. Schannwell CM, Schneppenheim M, Perings S, Plehn G, Stauer BE (2002) Left ventricular diastolic dysfunction as an early manifestation of diabetic cardiomyopathy. Cardiology 98:33-39

38. Shishehbor MH, Hoogwerf BJ, Schoenhagen P, Marso SP, Sun JP, Li J, Klein AL, Thomas JD, Garcia MJ (2003) Relation of hemoglobin A1c to left ventricular relaxation in patients with type 1 diabetes mellitus and without overt heart disease. Am J Cardiol 91:1514-1517

39. Grandi AM, Piantanida E, Franzetti I, Bernasconi M, Maresca A, Marnini P, Guasti L, Venco A (2006) Effect of glycemic control on left ventricular diastolic function in type 1 diabetes mellitus. Am J Cardiol 97:71-76

40. Palmieri V, Capaldo B, Russo C, Iaccarino M, Di Minno G, Riccardi G, Celentano A (2006) Left ventricular chamber and 
myocardial systolic function reserve in patients with type 1 diabetes mellitus: insight from traditional and Doppler tissue imaging echocardiography. J Am Soc Echocardiogr 19:848-856

41. Gul K, Celebi AS, Kacmaz F, Ozcan OC, Ustun I, Berker D, Aydin Y, Delibasi T, Guler S, Barazi AO (2009) Tissue Doppler imaging must be performed to detect early left ventricular dysfunction in patients with type 1 diabetes mellitus. Eur $\mathbf{J}$ Echocardiogr 10:841-846

42. Nadeau KJ, Regensteiner JG, Bauer TA, Brown MS, Dorosz JL, Hull A, Zeitler P, Draznin B, Reusch JE (2010) Insulin resistance in adolescents with type 1 diabetes and its relationship to cardiovascular function. J Clin Endocrinol Metab 95:513-521

43. Picano E, Pelosi G, Marzilli M, Lattanzi F, Benassi A, Landini L, L'Abbate A (1990) In vivo quantitative ultrasonic evaluation of myocardial fibrosis in humans. Circulation 81:58-64

44. Pérez JE, McGill JB, Santiago JV, Schechtman KB, Waggoner AD, Miller JG, Sobel BE (1992) Abnormal myocardial acoustic properties in diabetic patients and their correlation with the severity of disease. J Am Coll Cardiol 19:1154-1162

45. Di Bello V, Talarico L, Picano E, Di Muro C, Landini L, Paterni M, Matteucci E, Giusti C, Giampietro O (1995) Increased echodensity of myocardial wall in the diabetic heart: an ultrasound tissue characterization study. J Am Coll Cardiol 25:1408-1415

46. Kwong RY, Sattar H, Wu H, Vorobiof G, Gandla V, Steel K, Siu S, Brown KA (2008) Incidence and prognostic implication of unrecognized myocardial scar characterized by cardiac magnetic resonance in diabetic patients without clinical evidence of myocardial infarction. Circulation 118:1011-1020

47. Ha JW, Lee HC, Kang ES, Ahn CM, Kim JM, Ahn JA, Lee SW, Choi EY, Rim SJ, Oh JK, Chung N (2007) Abnormal left ventricular longitudinal functional reserve in patients with diabetes mellitus: implication for detecting subclinical myocardial dysfunction using exercise tissue Doppler echocardiograpjhy. Heart 93:1571-1576

48. Acar G, Akcay A, Sokmen A, Ozkaya M, Guler E, Sokmen G, Kaya H, Nacar B, Tuncer C (2009) Assessment of atrial electromechanical delay, diastolic functions, and left atrial mechanical functions in patients with type 1 diabetes mellitus. J Am Soc Echocardiogr 22:732-738

49. Poirier P, Bogaty P, Garneau C, Marois L, Dumesnil JG (2001) Diastolic dysfunction in normotensive men with well-controlled type 2 diabetes: importance of maneuvers in echocardiographic screening for preclinical diabetic cardiomyopathy. Diabetes Care 24:5-10

50. Zabalgoitia M, Ismaeil MF, Anderson L, Maklady FA (2001) Prevalence of diastolic dysfunction in normotensive, asymptomatic patients with well-controlled type 2 diabetes mellitus. Am J Cardiol 87:320-323

51. Boyer JK, Thanigaraj S, Schechtman KB, Pérez JE (2004) Prevalence of ventricular diastolic dysfunction in asymptomatic, normotensive patients with diabetes mellitus. Am J Cardiol 93:870-875

52. Kosmala W, Kucharski W, Przewlocka-Kosmala M, Mazurek W (2004) Comparison of left ventricular function by tissue Doppler imaging in patients with diabetes mellitus without systemic hypertension versus diabetes mellitus with systemic hypertension. Am J Cardiol 94:395-399

53. Di Bonito P, Moio N, Cavuto L, Covino G, Murena E, Scilla C, Turco S, Capaldo B, Sibilio G (2005) Early detection of diabetic cardiomyopathy: usefulness of tissue Doppler imaging. Diabet Med 22:1720-1725

54. Andersen NH, Poulsen SH, Eiskjaer H, Poulsen PL, Mogensen CE (2003) Decreased left ventricular longitudinal contraction in normotensive and normoalbuminuric patients with type II diabetes mellitus: a Doppler tissue tracking and strain rate echocardiography study. Clin Sci 105:59-66
55. Vinereanu D, Nicolaides E, Tweddel AC, Mädler CF, Holst B, Boden LE, Cinteza M, Rees AE, Fraser AG (2003) Subclinical left ventricular dysfunction in asymptomatic patients with type II diabetes mellitus, related to serum lipids and glycated haemoglobin. Clin Sci 105:591-599

56. Muranaka A, Yuda S, Tsuchihashi K, Hashimoto A, Nakata T, Miura T, Tsuzuki M, Wakabayashi C, Watanabe N, Shimamoto K (2009) Quantitative assessment of left ventricular and left atrial functions by strain rate imaging in diabetic patients with and without hypertension. Echocardiography 26:262-271

57. Ng AC, Delgado V, Bertini M, van der Meer RW, Rijzewijk LJ, Shanks M, Nucifora G, Smit JW, Diamant M, Romijn JA, de Roos A, Leung DY, Lamb HJ, Bax JJ (2009) Findings from left ventricular strain and strain rate imaging in asymptomatic patients with type 2 diabetes mellitus. Am J Cardiol 104:1398-1401

58. Ernande L, Rietzschel ER, Bergerot C, De Buyzere ML, Schnell F, Groisne L, Ovize M, Croisille P, Moulin P, Gillebert TC, Derumeaux G (2010) Impaired myocardial radial function in asymptomatic patients with type 2 diabetes mellitus: a speckletracking imaging study. J Am Soc Echocardiogr 23:1266-1272

59. Jellis CL, Stanton T, Leano R, Martin J, Marwick TH (2011) Usefulness of at rest and exercise hemodynamics to detect subclinical myocardial disease in type 2 diabetes mellitus. Am J Cardiol 107:615-621

60. Palmieri V, Capaldo B, Russo C, Iaccarino M, Pezzullo S, Quintavalle G, Di Minno G, Riccardi G, Celentano A (2008) Uncomplicated type 1 diabetes and preclinical left ventricular myocardial dysfunction: insights from echocardiography and exercise cardiac performance evaluation. Diabetes Res Clin Pract 79:262-268

61. Hare JL, Hordern MD, Leano R, Stanton T, Prins JB, Marwick TH (2011) Application of an exercise intervention on the evolution of diastolic dysfunction in patients with diabetes mellitus: efficacy and effectiveness. Circ Heart Fail 4:441-449

62. Gallego M, Casis O (2001) Regulation of cardiac transient outward potassium current by norepinephrine in normal and diabetic rats. Diabetes Metab Res Rev 17:304-309

63. Shimoni Y, Hunt D, Chuang M, Chen KY, Kargacin G, Severson DL (2005) Modulation of potassium currents by angiotensin and oxidative stress in cardiac cells from the diabetic rat. J Physiol 567:177-190

64. Pereira L, Matthes J, Schuster I, Valdivia HH, Herzig S, Richard S, Gómez AM (2006) Mechanisms of [Ca2+]I transient decrease in cardiomyopathy of $\mathrm{db} / \mathrm{db}$ type 2 diabetic mice. Diabetes 55:608-615

65. Lacombe VA, Viatchenko-Karpinski S, Terentyev D, Sridhar A, Emani S, Bonagura JD, Feldman DS, Györke S, Carnes CA (2007) Mechanisms of impaired calcium handling underlying subclinical diastolic dysfunction in diabetes. Am J Physiol Regul Integr Comp Physiol 293:R1787-R1797

66. Gallego M, Alday A, Urrutia J, Casis O (2009) Transient outward potassium channel regulation in healthy and diabetic hearts. Can J Physiol Pharmacol 87:77-83

67. Lagadic-Gossmann D, Buckler KJ, Le Prigent K, Feuvray D (1996) Altered $\mathrm{Ca}^{2+}$ handling in ventricular myocytes isolated from diabetic rats. Am J Physiol 270:H1529-H1537

68. Belke DD, Swanson EA, Dillmann WH (2004) Decreased sarcoplasmic reticulum activity and contractility in diabetic $\mathrm{db} / \mathrm{db}$ mouse heart. Diabetes 53:3201-3208

69. Yaras N, Bilginoglu A, Vassort G, Turan B (2007) Restoration of diabetes-induced abnormal local $\mathrm{Ca} 2+$ release in cardiomyocytes by angiontensin II receptor blockade. Am J Phyiol Heart Circ Physiol 292:H912-H920

70. Ishikawa T, Kajiwara H, Kurihara S (1999) Alterations in contractile properties and $\mathrm{Ca} 2+$ handling in streptozotocin-induced diabetic rat myocardium. Am J Physiol 277:H2185-H2194 
71. Zhang L, Cannell MB, Phillips AR, Cooper GJ, Ward ML (2008) Altered calcium homeostasis does not explain the contractile deficit of diabetic cardiomyopathy. Diabetes 57: 2158-2166

72. Howarth FC, Shafiullah M, Qureshi MA (2007) Chronic effects of type 2 diabetes mellitus on cardiac muscle contraction in the Goto-Kakizaki rat. Exp Physiol 92:1029-1036

73. Barth AS, Tomaselli GF (2009) Cardiac metabolism and arrhythmias. Circ Arrhythm Electrophysiol 2:327-335

74. Howarth FC, Qureshi MA, Hassan Z, Al Kury LT, Isaev D, Parekh K, Yammahi SR, Oz M, Adrian TE, Adeghate E (2011) Changing pattern of gene expression is associated with ventricular myocyte dysfunction and altered mechanisms of $\mathrm{Ca}^{2+}$ signaling in young type 2 Zucker diabetic fatty rat heart. Exp Physiol 96:325-337

75. Sah R, Oudit GY, Nguyen TT, Lim HW, Wickenden AD, Wilson GJ, Molkentin JD, Backx PH (2002) Inhibition of calcineurin and sarcolemmal $\mathrm{Ca}^{2+}$ influx protects cardiac morphology and ventricular function in $\mathrm{Kv} 4.2 \mathrm{~N}$ transgenic mice. Circulation 105:1850-1856

76. Wu P, Sato J, Zhao Y, Jaskiewcz J, Popov KM, Harris RA (1998) Starvation and diabetes increase the amount of pruvate dehydrogenase kinase isoenzyme 4 in rat heart. Biochem J 329: 197-201

77. Huang B, Wu P, Popov KM, Harris RA (2003) Starvation and diabetes reduce the amount of pyruvate dehydrogenase phosphatase in rat heart and kidney. Diabetes 52:1371-1376

78. Schroeder MA, Cochlin LE, Heather LC, Clarke K, Radda GK, Tyler DJ (2008) In vivo assessment of pyruvate dehydrogenase flux in the heart using hyperpolarized carbon-13 magnetic resonance. Proc Natl Acad Sci USA 105:12051-12056

79. Rozanski GJ, Xu Z, Zhang K, Patel KP (1998) Altered K ${ }^{+}$ current of ventricular myocytes in rats with chronic myocardial infarction. Am J Physiol 274:H259-H265

80. Huang B, Wu P, Bowker-Kinley MM, Harris RA (2002) Regulation of pyruvate dehydrogenase kinase expression by peroxisome proliferator-activated receptor-alpha ligands, glucocorticoids, and insulin. Diabetes 51:276-283

81. Sugden MC, Holness MJ (2006) Mechanisms underlying regulation of the expression and activities of the mammalian pyruvate dehydrogenase kinases. Arch Physiol Biochem 112:139-149

82. Marionneau C, Aimond F, Brunet S, Niwa N, Finck B, Kelly DP, Nerbonne JM (2008) PPARalpha-mediated remodeling of repolarizing voltage-gated $\mathrm{K}+(\mathrm{Kv})$ channels in a mouse model of metabolic cardiomyopathy. J Mol Cell Cardiol 44:1002-1015

83. Belke DD, Dillmann WH (2004) Altered cardiac calcium handling in diabetes. Curr Hypertens Rep 6:424-429

84. Bidasee KR, Zhang Y, Shao CH, Wang M, Patel KP, Dincer UD, Besch HR Jr (2004) Diabetes increases formation of advanced glycation end products on Sarco(endo)plasmic reticulum $\mathrm{Ca}^{2+}$-ATPase. Diabetes 53:463-473

85. Clark RJ, McDonough PM, Swanson E, Trost SU, Suzuki M, Fukuda M, Dillmann WH (2003) Diabetes and the accompanying hyperglycemia impairs cardiomyocyte calcium cycling through increased nuclear O-GlcNAcylation. J Biol Chem 278:44230-44237

86. Hu Y, Belke D, Suarez J, Swanson E, Clark R, Hoshijima M, Dillmann WH (2005) Adenovirus-mediated overexpression of O-GlcNAcase improves contractile function in the diabetic heart. Circ Res 96:1006-1013

87. Yaras N, Ugur M, Ozdemir S, Gurdal H, Purali N, Lacampagne A, Vassort G, Turan B (2005) Effects of diabetes on ryanodine receptor Ca release channel (RyR2) and $\mathrm{Ca}^{2+}$ homeostasis in rat heart. Diabetes 54:3082-3088

88. Malhotra A, Sanghi V (1997) Regulation of contractile proteins in diabetic heart. Cardiovasc Res 34:34-40
89. Falcao-Pires I, Palladini G, Gonçalves N, van der Velden J, Moreira-Gonçalves D, Miranda-Silva D, Salinaro F, Paulus WJ, Niessen HW, Perlini S, Leite-Moreira AF (2011) Distinct mechanisms for diastolic dysfunction in diabetes mellitus and chronic pressure-overload. Basic Res Cardiol 106:801-814

90. Jweied EE, McKinney RD, Walker LA, Brodsky I, Geha AS, Massad MG, Buttrick PM, de Tombe PP (2005) Depressed cardiac myofilament function in human diabetes mellitus. Am J Physiol Heart Circ Physiol 289:H2478-H2483

91. Taegtmeyer H (1994) Energy metabolism of the heart: from basic concepts to clinical application. Curr Prob Cardiol 19:59-113

92. Ingwall JS, Weiss RG (2004) Is the failing heart energy starved? On using chemical energy to support cardiac function. Circ Res 95:135-145

93. Knaapen P, Germans T, Knuuti J, Paulus WJ, Dijkmans PA, Allaart CP, Lammertsma AA, Visser FC (2007) Myocardial energetics and efficiency: current status of the noninvasive approach. Circulation 15:918-927

94. Madrazo JA, Kelly DP (2008) The PPAR trio: regulators of myocardial energy metabolism in health and disease. J Mol Cell Cardiol 44:968-975

95. Hafstad AD, Khalid AM, Hagve M, Lund T, Larsen TS, Severson DL, Clarke K, Berge RK, Aasum E (2009) Cardiac peroxisome proliferator-activated receptor- $\alpha$ activation causes increased fatty acid oxidation, reducing efficiency and postischaemic functional loss. Cardiovasc Res 83:519-526

96. Buchanan J, Mazumder PK, Hu P, Chakrabarti G, Roberts MW, Yun UJ, Cooksey RC, Litwin SE, Abel ED (2005) Reduced cardiac efficiency and altered substrate metabolism precedes the onset of hypoglycemia and contractile dysfunction in two mouse models of insulin resistance and obesity. Endocrinology 146:5341-5349

97. Hafstad AD, Solevåg GH, Severson DL, Larsen TS, Aasum E (2006) Perfused hearts from type 2 diabetic $(\mathrm{db} / \mathrm{db})$ mice show metabolic responsiveness to insulin. Am J Physiol Heart Circ Physiol 290:H1763-H1769

98. Desrois M, Sidell RJ, Gauguier D, King LM, Radda GK, Clarke $\mathrm{K}$ (2004) Initial steps of insulin signaling and glucose transport are defective in the type 2 diabetic rat heart. Cardiovasc Res 61:288-296

99. Deng JY, Huang JP, Lu LS, Hung LM (2007) Impairment of cardiac insulin signaling and myocardial contractile performance in high cholesterol/fructose-fed rats. Am J Physiol Heart Circ Physiol 293:H978-H987

100. Hue L, Taegtmeyer H (2009) The Randle cycle revisited: a new head for and old hat. Am J Physiol Endocrinol Metab 297:E578E591

101. Heather LC, Clarke K (2011) Metabolism, hypoxia and the diabetic heart. J Mol Cell Cardiol 50:598-605

102. Bugger H, Abel ED (2010) Mitochondria in the diabetic heart. Cardiovasc Res 88:229-240

103. Echtay KS, Roussel D, St-Pierre J, Jekabsons MB, Cadenas S, Stuart JA, Harper JA, Roebuck SJ, Morrison A, Pickering S, Clapham JC, Brand MD (2002) Superoxide activates mitochondrial uncoupling proteins. Nature 415:96-99

104. Echtay KS, Esteves TC, Pakay JL, Jekabsons MB, Lambert AJ, Portero-Otín M, Pamplona R, Vidal-Puig AJ, Wang S, Roebuck SJ, Brand MD (2003) A signaling role for 4-hydroxy-2-neonal in regulation of mitochondrial uncoupling. EMBO J 22:4103-4110

105. Serpillon S, Floyd BC, Gupte RS, George S, Kozicky M, Neito V, Recchia F, Stanley W, Wolin MS, Gupte SA (2009) Superoxide production of $\mathrm{NAD}(\mathrm{P}) \mathrm{H}$ oxidase and mitochondria is increased in genetically obese and hyperglycemic rat heart and aorta before the development of cardiac dysfunction. The role of glucose-6-phosphate dehydrogenase-derived NADPH. Am J Physiol Heart Circ Physiol 297:H153-H162 
106. Li S, Li X, Li YL, Shao CH, Bidasee KR, Rozanski GJ (2007) Insulin regulation of glutathione and contractile phenotype in diabetic rat ventricular myocytes. Am J Physiol Heart Circ Physiol 292:H1619-H1629

107. Scheuermann-Freestone M, Madsen PL, Manners D, Blamire AM, Buckingham RE, Styles P, Radda GK, Neubauer S, Clarke K (2003) Abnormal cardiac and skeletal muscle energy metabolism in patients with type 2 diabetes. Circulation 107:3040-3046

108. Rijzewijk LJ, Jonker JT, van der Meer RW, Lubberink M, de Jong HW, Romijn JA, Bax JJ, de Roos A, Heine RJ, Twisk JW, Windhorst AD, Lammertsma AA, Smit JW, Diamant M, Lamb HJ (2010) Effects of hepatic triglyceride content on myocardial metabolism in type 2 diabetes. J Am Coll Cardiol 56:225-233

109. Berg TJ, Snorgaard O, Faber J, Torjesen PA, Hildebrandt P, Mehlsen J, Hanssen KF (1999) Serum levels of advanced glycation end products are associated with left ventricular diastolic function in patients with type 1 diabetes. Diabetic Care 22:1186-1190

110. Yoshida N, Okumura K, Aso Y (2005) High serum pentosidine concentrations are associated with increased arterial stiffness and thickness in patients with type 2 diabetes. Metabolism 54:345-350

111. Daroux M, Prévost G, Maillard-Lefebvre H, Gaxatte C, D'Agati VD, Schmidt AM, Boulanger E (2010) Advanced glycation endproducts: implications for diabetic and non-diabetic nephropathies. Diabetes Metab 36:1-10

112. Verzijl N, DeGroot J, Thorpe SR, Bank RA, Shaw JN, Lyons TJ, Bijlsma JW, Lafeber FP, Baynes JW, TeKoppele JM (2000) Effect of collagen turnover on the accumulation of advanced glycation end products. J Biol Chem 275:39027-39031

113. Lapolla A, Piarulli F, Sartore G, Ceriello A, Ragazzi E, Reitano R, Baccarin L, Laverda B, Fedele D (2007) Advanced glycation end products and antioxidant status in type 2 diabetic patients with and without peripheral artery disease. Diabetes Care 30:670-676

114. Norton GR, Candy G, Woodiwiss AJ (1996) Aminoguanidine prevents the decreased myocardial compliance produced by streptozotocin-induced diabetes mellitus in rats. Circulation 93:1905-1912

115. Wu MS, Liang JT, Lin YD, Wu ET, Tseng YZ, Chang KC (2008) Aminoguanidine prevents the impairment of cardiac pumping mechanics in rats with streptozotocin and nicotinamide-induced type 2 diabetes. Br J Pharmacol 154:758-764

116. Liu J, Masurekar MR, Vatner DE, Jyothirmayi GN, Regan TJ, Vatner SF, Meggs LG, Malhotra A (2003) Glycation endproduct cross-link breaker reduces collagen and improves cardiac function in aging diabetic heart. Am J Physiol Heart Circ Physiol 285:H2587-H2591

117. Little WC, Zile MR, Kitzman DW, Hundley WG, O'Brien TX, Degroof RC (2005) The effect of alagebrium chloride (ATL711), a novel glucose cross-link breaker, in the treatment of elderly patients with diastolic heart failure. J Card Fail 11: 191-195

118. Reuter H, Adam C, Grönke S, Zobel C, Frank KF, MüllerEhmsen J, Brabender J, Schwinger RH (2006) The increased angiotensin II (type 1) receptor density in myocardium of type 2 diabetic patients is prevented by blockade of the renin-angiotensin system. Diabetologia 49:3067-3074

119. Hotta H, Miura T, Miki T, Togashi N, Maeda T, Kim SJ, Tanno M, Yano T, Kuno A, Itoh T, Satoh T, Terashima Y, Ishikawa S, Shimamoto K (2010) Angiotensin II type 1 receptor-mediated upregulation of calcineurin activity underlies impairment of cardioprotective signaling in diabetic hearts. Circ Res 106: $129-132$

120. Rosenkranz S (2004) TGF-betal and angiotensin networking in cardiac remodeling. Cardiovasc Res 63:423-432
121. Chen K, Mehta JL, Li D, Joseph L, Joseph J (2004) Transforming growth factor beta receptor endoglin is expressed in cardiac fibroblasts and modulates profibrogenic actions of angiotensin II. Circ Res 95:1167-1173

122. Factor SM, Okun EM, Minase T (1980) Capillary microaneurysms in the human diabetic heart. N Engl J Med 302:384-388

123. Factor SM, Minase T, Cho S, Fein F, Capasso JM, Sonnenblick EH (1984) Coronary microvascular abnormalities in the hypertensive-diabetic rat. A primary cause of cardiomyopathy? Am J Pathol 116:9-20

124. Yoon YS, Uchida S, Masuo O, Cejna M, Park JS, Gwon HC, Kirchmair R, Bahlman F, Walter D, Curry C, Hanley A, Isner JM, Losordo DW (2005) Progressive attenuation of myocardial vascular endothelial growth factor expression is a seminal event in diabetic cardiomyopathy: restoration of microvascular homeostasis and recovery of cardiac function in diabetic cardiomyopathy after replenishment of local vascular endothelial growth factor. Circulation 111:2073-2085

125. He Z, Opland DM, Way KJ, Ueki K, Bodyak N, Kang PM, Izumo S, Kulkarni RN, Wang B, Liao R, Kahn CR, King GL (2006) Regulation of vascular endothelial growth factor expression and vascularization in the myocardium by insulin receptor and PI3K/Akt pathways in insulin resistance and ischemia. Arterioscler Thromb Vasc Biol 26:787-793

126. Chou E, Suzuma I, Way KJ, Opland D, Clermont AC, Naruse K, Suzuma K, Bowling NL, Vlahos CJ, Aiello LP, King GL (2002) Decreased cardiac expression of vascular endothelial growth factor and its receptors in insulin-resistant and diabetic states: a possible explanation for impaired collateral formation in cardiac tissue. Circulation 105:373-379

127. Marfella R, Esposito K, Nappo F, Siniscalchi M, Sasso FC, Portoghese M, Di Marino MP, Baldi A, Cuzzocrea S, Di Filippo C, Barboso G, Baldi F, Rossi F, D’Amico M, Giugliano D (2004) Expression of angiogenic factors during acute coronary syndromes in human type 2 diabetes. Diabetes 53:2383-2391

128. Sasso FC, Torella D, Carbonara O, Ellison GM, Torella M, Scardone M, Marra C, Nasti R, Marfella R, Cozzolino D, Indolfi C, Cotrufo M, Torella R, Salvatore T (2005) Increased vascular endothelial growth factor expression but impaired vascular endothelial growth factor receptor signaling in the myocardium of type 2 diabetic patients with chronic coronary heart disease. J Am Coll Cardiol 46:827-834

129. Yu Y, Ohmori K, Kondo I, Yao L, Noma T, Tsuji T, Mizushige K, Kohno M (2002) Correlation of functional and structural alterations of the coronary arterioles during development of type II diabetes mellitus in rats. Cardiovasc Res 56:303-311

130. Hayashi T, Sohmiya K, Ukimura A, Endoh S, Mori T, Shimomura H, Okabe M, Terasaki F, Kitaura Y (2003) Angiotensin II receptor blockade prevents microangiopathy and preserves diastolic function in the diabetic rat heart. Heart 89:1236-1242

131. Mizuno R, Fujimoto S, Saito Y, Nakamura S (2010) Exerciseinduced delayed onset of left ventricular early relaxation in association with coronary microcirculatory dysfunction in patients with diabetes mellitus. J Card Fail 16:211-217

132. Zieman SJ, Melenovsky V, Clattenburg L, Corretti MC, Capriotti A, Gerstenblith G, Kass DA (2007) Advanced glycation endproduct crosslink breaker (alagebrium) improves endothelial function in patients with isolated systolic hypertension. J Hypertens 25:577-583

133. Forrat R, Sebbag L, Wiernsperger N, Guidollet J, Renaud S, de Lorgeril M (1993) Acute myocardial infarction in dogs with experimental diabetes. Cardiovasc Res 27:1908-1912

134. Marfella R, D’Amico M, Di Filippo C, Piegari E, Nappo F, Esposito K, Berrino L, Rossi F, Giugliano D (2002) Myocardial infarction in diabetic rats: role of hyperglycaemia on infarct size 
and early expression of hypoxia-inducible factor 1 . Diabetologia 45:1172-1181

135. Marfella R, Di Filippo C, Esposito K, Nappo F, Piegari E, Cuzzocrea S, Berrino L, Rossi F, Giugliano D, D'Amico M (2004) Absence of inducible nitric oxide synthase reduces myocardial damage during ischemia reperfusion in streptozotocin-induced hyperglycemic mice. Diabetes 53:454-462

136. Xiao CY, Chen M, Zsengellér Z, Szabó C (2004) Poly(ADPribose) polymerase contributes to the development of myocardial infarction in diabetic rats and regulates the nuclear translocation of apoptosis-inducing factor. J Pharmacol Exp Ther 310:498-504

137. Di Filippo C, Marfella R, Cuzzocrea S, Piegari E, Petronella P, Giugliano D, Rossi F, D’Amico M (2005) Hyperglycemia in streptozotocin-induced diabetic rat increases infarct size associated with low levels of myocardial HO-1 during ischemia/ reperfusion. Diabetes 54:803-810

138. Liu X, Wei J, Peng DH, Layne MD, Yet SF (2005) Absence of heme oxygenase-1 exacerbates myocardial ischemia/reperfusion injury in diabetic mice. Diabetes 54:778-784

139. Thirunavukkarasu M, Penumathsa SV, Koneru S, Juhasz B, Zhan L, Otani H, Bagchi D, Das DK, Maulik N (2007) Reseveratrol alleviates cardiac dysfunction in streptozotocin-induced diabetes: role of nitric oxide, thioredoxin, and heme oxygenase. Free Radic Biol Med 43:720-729

140. Jordan JE, Simandle SA, Tulbert CD, Busija DW, Miller AW (2003) Fructose-fed rats are protected against ischemia/reperfusion injury. J Pharmacol Exp Ther 307:1007-1011

141. Katakam PV, Jordan JE, Snipes JA, Tulbert CD, Miller AW, Busija DW (2007) Myocardial preconditioning against ischemia-reperfusion injury is abolished in Zucker obese rats with insulin resistance. Am J Physiol Regul Integr Comp Physiol 292:R920-R926

142. La Bonte LR, Davis-Gorman G, Stahl GL, McDonagh PF (2008) Complement inhibition reduces injury in the type 2 diabetic heart following ischemia/reperfusion. Am J Physiol Heart Circ Physiol 294:H1282-H1290

143. Miki T, Miura T, Hotta H, Tanno M, Yano T, Sato T, Terashima Y, Takada A, Ishikawa S, Shimamoto K (2009) Endoplasmic reticulum stress in diabetic hearts abolishes erythropoietininduced myocardial protection by impairment of phosphor-glycogen synthase kinase-3beta-mediated suppression of mitochondrial permeability transition. Diabetes 58:2863-2872

144. Bouhidel O, Pons S, Souktani R, Zini R, Berdeaux A, Ghaleh B (2008) Myocardial ischemic postconditioning against ischemiareperfusion is impaired in ob/ob mice. Am J Physiol Heart Circ Physiol 295:H1580-H1586

145. Liu Y, Thornton JD, Cohen MV, Downey JM, Schaffer SW (1993) Streptozotocin-induced non-insulin-dependent diabetes protects the heart from infarction. Circulation 88:1273-1278

146. Hadour G, Ferrera R, Sebbag L, Forrat R, Delaye J, de Lorgeril $M$ (1998) Improved myocardial tolerance to ischaemia in the diabetic rabbit. J Mol Cell Cardiol 30:1869-1875

147. Ravingerová T, Neckár J, Kolár F (2003) Ischemic tolerance of rat hearts in acute and chronic phases of experimental diabetes. Mol Cell Biochem 249:167-174

148. Mozaffari MS, Schaffer SW (2003) Effect of hypertension and hypertension-glucose intolerance on myocardial ischemic injury. Hypertension 42:1042-1049

149. Xu G, Takashi E, Kudo M, Ishiwata T, Naito Z (2004) Contradictory effects of short- and long-term hyperglycemias on ischemic injury of myocardium via intracellular signaling pathway. Exp Mol Pathol 76:57-65

150. Ma G, Al-Shabrawey M, Johnson JA, Datar R, Tawfik HE, Guo D, Caldwell RB, Caldwell RW (2006) Protection against myocardial ischemia/reperfusion injury by short-term diabetes: enhancement of VEGF formation, capillary density, and activation of cell survival signaling. Naunyn Schmiedebergs Arch Pharmacol 373:415-427

151. Galagudza MM, Nekrasova MK, Syrenskii AV, Nifontov EM (2007) Resistance of the myocardium to ischemia and the efficacy of ischemic preconditioning in experimental diabetes mellitus. Neurosci Behav Physiol 37:489-493

152. Kravchuk E, Grineva E, Bairamov A, Galagudza M, Vlasov T (2011) The effect of metformin on the myocardial tolerance to ischemia-reperfusion injury in the rat model of diabetes mellitus type II. Exp Diabetes Res 2011:907496

153. Kristiansen SB, Løfgren B, Støttrup NB, Khatir D, NielsenKudsk JE, Nielsen TT, Bøtker HE, Flyvbjerg A (2004) Ischaemic preconditioning does not protect the heart in obese and lean animal models of type 2 diabetes. Diabetologia 47:1716-1721

154. Kristiansen SB, Løfgren B, Nielsen JM, Støttrup NB, Buhl ES, Nielsen-Kudsk JE, Nielsen TT, Rungby J, Flyvbjerg A, Bøtker HE (2011) Comparison of two sulfonylureas with high and low myocardial $\mathrm{K}_{\text {ATP }}$ channel affinity on myocardial infarct size and metabolism in a rat model of type 2 diabetes. Diabetologia 54:451-458

155. Vogel WM, Apstein CS (1988) Effects of alloxan-induced diabetes on ischemia-reperfusion injury in rabbit hearts. Circ Res 62:975-982

156. Joyeux M, Faure P, Godin-Ribuot D, Halimi S, Patel A, Yellon DM, Demenge P, Ribuot C (1999) Heat stress fails to protect myocardium of streptozotocin-induced diabetic rats against infarction. Cardiovasc Res 43:939-946

157. Kersten JR, Toller WG, Gross ER, Pagel PS, Warltier DC (2000) Diabetes abolishes ischemic preconditioning: role of glucose, insulin, and osmolality. Am J Physiol Heart Circ Physiol 278:H1218-H1224

158. Kersten JR, Montgomery MW, Ghassemi T, Gross ER, Toller WG, Pagel PS, Warltier DC (2001) Diabetes and hyperglycemia impair activation of mitochondrial $\mathrm{K}_{\mathrm{ATP}}$ channels. Am J Physiol Heart Circ Physiol 280:H1744-H1750

159. Nieszner E, Posa I, Kocsis E, Pogátsa G, Préda I, Koltai MZ (2002) Influence of diabetic state and that of different sulfonylureas on the size of myocardial infarction with and without ischemic preconditioning in rabbits. Exp Clin Endocrionol Diabetes 110:212-218

160. Ebel D, Müllenheim J, Frässdorf J, Heinen A, Huhn R, Bohlen T, Ferrari J, Südkamp H, Preckel B, Schlack W, Thämer V (2003) Effect of acute hyperglycemia and diabetes mellitus with and without short-term insulin treatment on myocardial ischaemic late preconditioning in the rabbit heart in vivo. Pflugers Arch 446:175-182

161. Gross ER, Hsu AK, Gross GJ (2007) Diabetes abolishes morphin-induced cardioprotection via multiple pathways upstream of glycogen synthase kinse-3beta. Diabetes 56:127-136

162. Ghaboura N, Tamareille S, Ducluzeau PH, Grimaud L, Loufrani L, Croué A, Tourmen Y, Henrion D, Furber A, Prunier F (2011) Diabetes mellitus abrogates erythropoietin-induced cardioprotection against ischemic-reperfusion injury by alteration of the RISK/GSK- $3 \beta$ signaling. Basic Res Cardiol 106:147-162

163. Drenger B, Ostrovsky IA, Barak M, Nechemia-Arbely Y, Ziv E, Axelrod JH (2011) Diabetes blockade of sevoflurane postconditioning is not restored by insulin in the rat heart: phosphorylated signal transducer and activator of transcription 3- and phosphatidylinositol 3-kinase-mediated inhibition. Anesthesiology $114: 1364-1372$

164. Okazaki T, Otani H, Shimazu T, Yoshioka K, Fujita M, Katano T, Ito S, Iwasaka T (2011) Reversal of inducible nitric oxide synthase uncoupling unmasks tolerance to ischemia/reperfusion injury in the diabetic rat heart. J Mol Cell Cardiol 50:534-544 
165. Przyklenk K, Maynard M, Greiner DL, Whittaker P (2011) Cardioprotection with postconditioning: loss of efficacy in murine models of type- 2 and type- 1 diabetes. Antioxid Redox Signal 14:781-790

166. Tsang A, Hausenloy DJ, Mocanu MM, Carr RD, Yellon DM (2005) Preconditioning the diabetic heart: the importance of Akt phosphorylation. Diabetes 54:2360-2364

167. Bhamra GS, Hausenloy DJ, Davidson SM, Carr RD, Paiva M, Wynne AM, Mocanu MM, Yellon DM (2008) Metformin protects the ischemic heart by the Akt-mediated inhibition of mitochondrial permeability transition pore opening. Basic Res Cardiol 103:274-284

168. Bulhak AA, Jung C, Ostenson CG, Lundberg JO, Sjöquist PO, Pernow J (2009) PPAR-alpha activation protects the type 2 diabetic myocardium against ischemia-reperfusion injury: involvement of the PI3-kinase/Akt and NO pathway. Am J Physiol Heart Circ Physiol 296:H719-H727

169. Matsumoto S, Cho S, Tosaka S, Ureshino H, Maekawa T, Hara T, Sumikawa K (2009) Pharmacological preconditioning in type 2 diabetic rat hearts: the role of mitochondrial ATP-sensitive potassium channels and the phosphatidylinositol 3-kinase-Akt pathway. Cardiovasc Drug Ther 23:263-270

170. Kersten JR, Schmeling TG, Orth KG, Pagel PS, Warltier WC (1998) Acute hyperglycemia abolishes ischemic preconditioning in vivo. Am J Physiol 275:H721-H725

171. Wong VW, Mardini M, Cheung NW, Mihailidou AS (2011) High-dose insulin in experimental myocardial infarction in rabbits: protection against effects of hyperglycemia. J Diabetes Complications 25:122-128

172. Kehl F, Krolikowski JG, Mraovic B, Pagel PS, Warltier DC, Kersten JR (2002) Hyperglycemia prevents isoflurane-induced preconditioning against myocardial infarction. Anesthesiology 96:183-188

173. Su H, Sun X, Ma H, Zhang HF, Yu QJ, Huang C, Wang XM, Luan RH, Jia GL, Wang HC, Gao F (2007) Aute hyperglycemia exacerbates myocardial ischemia/reperfusion injury and blunts cardioprotective effect of GIK. Am J Physiol Endocrinol Metab 293:E629-E635

174. Weber NC, Goletz C, Huhn R, Grueber Y, Preckel B, Schlack W, Ebel D (2008) Blockade of anaesthetic-induced preconditioning in the hyperglycaemic myocardium: the regulation of different mitogen-activated protein kinases. Eur J Pharmacol 592:48-54

175. Gu W, Kehl F, Krolikowski JG, Pagel PS, Warltier DC, Kersten JR (2008) Simvastatin restores ischemic preconditioning in the presence of hyperglycemia through a nitric oxide-mediated mechanism. Anesthesiology 108:634-642

176. Huhn R, Heinen A, Weber NC, Hollmann MW, Schlack W, Preckel B (2008) Hyperglycaemia blocks sevoflurane-induced postconditioning in the rat heart in vivo: cardioprotection can be restored by blocking the mitochondrial permeability transition pore. Br J Anaesth 100:465-471

177. Amour J, Brzezinska AK, Jager Z, Sullivan C, Weihrauch D, Du J, Vladic N, Shi Y, Warltier DC, Pratt PF Jr, Kersten JR (2010) Hyperglycemia adversely modulates endothelial nitric oxide synthase during anesthetic preconditioning through tetrahydrobiopterin- and heat shock protein 90-mediated mechanisms. Anesthesiology 112:576-585

178. Raphael J, Gozal Y, Navot N, Zuo Z (2010) Hyperglycemia inhibits anesthetic-induced postconditioning in the rabbit heart via modulation of phosphatidylinositol-3-kinase/Akt and endothelial nitric oxide synthase signaling. J Cardiovasc Pharmacol 55:348-357

179. Du Toit EF, Smith W, Muller C, Strijdom H, Stouthammer B, Woodiwiss AJ, Norton GR, Lochner A (2008) Myocardial susceptibility to ischemia-reperfusion injury in a prediabetic model of dietary-induced obesity. Am J Physiol Heart Circ Physiol 294:H2336-H2343

180. Thim T, Bentzon JF, Kristiansen SB, Simonsen U, Andersen HL, Wassermann K, Falk E (2006) Size of myocardial infarction induced by ischaemia/reperfusion is unaltered in rats with metabolic syndrome. Clin Sci (Lond) 110:665-671

181. Wagner C, Kloeting I, Strasser RH, Weinbrenner C (2008) Cardioprotection by postconditioning is lost in WOKW rats with metabolic syndrome: role of glycogen synthase kinase 3 beta. J Cardiovasc Pharmacol 52:430-437

182. Yadav HN, Singh M, Sharma PL (2010) Involvement of GSK$3 \beta$ in attenuation of the cardioprotective effect of ischemic preconditioning in diabetic rat heart. Mol Cell Biochem 343:75-81

183. Ishihara M, Inoue I, Kawagoe T, Shimatani Y, Kurisu S, Nishioka K, Kouno Y, Umemura T, Nakamura S, Sato H (2001) Diabetes mellitus prevents ischemic preconditioning in patients with a first acute anterior wall myocardial infarction. J Am Coll Cardiol 38:1007-1011

184. Lee TM, Chou TF (2003) Impairment of myocardial protection in type 2 diabetic patients. J Clin Endocrinol Metab 88:531-537

185. Ovünç $\mathrm{K}$ (2000) Effects of glibenclamide, a $\mathrm{K}_{\mathrm{ATP}}$ channel blocker, on warm-up phenomenon in type II diabetic patients with chronic stable angina pectoris. Clin Cardiol 23:535-539

186. Hassouna A, Loubani M, Matata BM, Fowler A, Standen NB, Galiñanes M (2006) Mitochondrial dysfunction as the cause of the failure to precondition the diabetic human myocardium. Cardiovasc Res 69:450-458

187. Sivaraman V, Hausenloy DJ, Wynne AM, Yellon DM (2010) Preconditioning the diabetic human myocardium. J Cell Mol Med 14:1740-1746

188. Ueda Y, Kitakaze M, Komamura K, Minamino T, Asanuma H, Sato H, Kuzuya T, Takeda H, Hori M (1999) Pravastatin restored the infarct size-limiting effect of ischemic preconditioning blunted by hypercholesterolemia in the rabbit model of myocardial infarction. J Am Coll Cardiol 34:2120-2125

189. Kyriakides ZS, Psychari S, Iliodromitis EK, Kolettis TM, Sbarouni E, Kremastinos DT (2002) Hyperlipidemia prevents the expected reduction of myocardial ischemia on repeated balloon inflations during angioplasty. Chest 121:1211-1215

190. Ungi I, Ungi T, Ruzsa Z, Nagy E, Zimmermann Z, Csont T, Ferdinandy P (2005) Hypercholesterolemia attenuates the antiischemic effect of preconditioning during coronary angioplasty. Chest 128:1623-1628

191. Ernande L, Bergerot C, Rietzschel ER, De Buyzere ML, Thibault $\mathrm{H}$, Pignonblanc PG, Croisille P, Ovize M, Groisne L, Moulin P, Gillebert TC, Derumeaux G (2011) Diastolic dysfunction in patients with type 2 diabetes mellitus: is it really the first marker of diabetic cardiomyopathy? J Am Soc Echocardiogr 24:1268-1275

192. McGavock JM, Lingvay I, Zib I, Tillery T, Salas N, Unger R, Levine BD, Raskin P, Victor RG, Szczepaniak LS (2007) Cardiac steatosis in diabetes mellitus: a ${ }^{1} \mathrm{H}$-magnetic resonance spectroscopy study. Circulation 116:1170-1175

193. Rijzewijk LJ, van der Meer RW, Smit JW, Diamant M, Bax JJ, Hammer S, Romijn JA, de Roos A, Lamb HJ (2008) Myocardial steatosis is an independent predictor of diastolic dysfunction in type 2 diabetes mellitus. J Am Coll Cardiol 52:1793-1799

194. Ng ACT, Delgado V, Bertini M, van der Meer RW, Rijzewijk LJ, Hooi Ewe S, Siebelink HM, Smit JW, Diamant M, Romijn JA, de Roos A, Leung DY, Lamb HJ, Bax JJ (2010) Myocardial steatosis and biventricular strain and strain rate imaging in patients with type 2 diabetes mellitus. Circulation 122: $2538-2544$

195. Torffvit O, Lövestam-Adrian M, Agardh E, Agardh CD (2005) Nephropathy, but not retinopathy, is associated with the 
development of heart disease in type 1 diabetes: a 12-year observation study of 462 patients. Diabet Med 22:723-729

196. Turnbull FM, Abraira C, Anderson RJ, Byington RP, Chalmers JP, Duckworth WC, Evans GW, Gerstein HC, Holman RR, Moritz TE, Neal BC, Ninomiya T, Patel AA, Paul SK, Travert F, Woodward M (2009) Intensive glucose control and macrovascular outcomes in type 2 diabetes. Diabetologia 52:2288-2298

197. von Bibra H, Hansen A, Dounis V, Bystedt T, Malmberg K, Rydén L (2004) Augmented metabolic control improves myocardial diastolic function and perfusion in patients with noninsulin dependent diabetes. Heart 90:1483-1484

198. Hordern MD, Coombes JS, Cooney LM, Jeffriess L, Prins JB, Marwick TH (2009) Effects of exercise intervention on myocardial function in type 2 diabetes. Heart 95:1343-1349

199. Gaede P, Vedel P, Larsen N, Jensen GV, Parving HH, Pedersen O (2003) Multifactorial intervention and cardiovascular disease in patients with type 2 diabetes. N Engl J Med 348:383-393

200. Eurich DT, McAlister FA, Blackburn D, Majumdar SR, Tsuyuki RT, Varney J, Johnson JA (2007) Benefits and harms of antidiabetic agents in patients with diabetes and heart failure: systematic review. Br Med J 335:497-586

201. Andersson C, Olesen JB, Hansen PR, Weeke P, Norgaard ML, Jørgensen CH, Lange T, Abildstrøm SZ, Schramm TK, Vaag A, Køber L, Torp-Pedersen C, Gislason GH (2010) Metformin treatment is associated with a low risk of mortality in diabetic patients with heart failure: a retrospective nationwide cohort study. Diabetologia 53:2546-2553

202. Aguilar D, Chan W, Bozkurt B, Ramasubbu K, Deswal A (2011) Metformin use and mortality in ambulatory patients with diabetes and heart failure. Circ Heart Fail 4:53-58

203. Tang WH, Francis GS, Hoogwerf BJ, Young JB (2003) Fluid retention after initiation of thiazolidinedione therapy in diabetic patients with established chronic heart failure. J Am Coll Cardiol 41:1394-1398

204. Masoudi FA, Inzucchi SE, Wang Y, Havranek EP, Foody JM, Krumholz HM (2005) Thiazolidinediones, metformin, and outcomes in older patients with diabetes and heart failure: an observational study. Circulation 111:583-590

205. Aguilar D, Bozkurt B, Pritchett A, Petersen NJ, Deswal A (2007) The impact of thiazolidinedione use on outcomes in ambulatory patients with diabetes mellitus and heart failure. J Am Coll Cardiol 50:32-36

206. Erdmann E, Wilcox RG (2008) Weighing up the cardiovascular benefits of thiazolidinedione therapy: the impact of increased risk of heart failure. Eur Heart J 29:12-20

207. Horio T, Suzuki M, Suzuki K, Takamisawa I, Hiuge A, Kamide K, Takiuchi S, Iwashima Y, Kihara S, Funahashi T, Yoshimasa
Y, Kawano Y (2005) Pioglitazone improves left ventricular diastolic function in patients with essential hypertension. Am J Hypertens 18:949-957

208. van der Meer RW, Rijzewijk LJ, de Jong HW, Lamb HJ, Lubberink M, Romijn JA, Bax JJ, de Roos A, Kamp O, Paulus WJ, Heine RJ, Lammertsma AA, Smit JW, Diamant M (2009) Pioglitazone improves cardiac function and alters myocardial substrate metabolism without affecting cardiac triglyceride accumulation and high-energy phosphate metabolism in patients with well-controlled type 2 diabetes mellitus. Circulation 119:2069-2077

209. Shindler DM, Kostis JB, Yusuf S, Quinones MA, Pitt B, Stewart D, Pinkett T, Ghali JK, Wilson AC (1996) Diabetes mellitus, a predictor of morbidity and mortality in the Studies of Left Ventricular Dysfunction (SOLVD) Trials and Registry. Am J Cardiol 77:1017-1020

210. Rydén L, Armstrong PW, Cleland JG, Horowitz JD, Massie BM, Packer M, Poole-Wilson PA (2000) Efficacy and safety of highdose lisinopril in chronic heart failure patients at high cardiovascular risk, including those with diabetes mellitus. Results from the ATLAS trial. Eur Heart J 21:1967-1978

211. Haas SJ, Vos T, Gilbert RE, Krum H (2003) Are beta-blockers as efficacious in patients with diabetes mellitus as in patients without diabetes mellitus who have chronic heart failure? A meta-analysis of large-scale clinical trials. Am Heart J 146: 848-853

212. de Boer RA, Doehner W, van der Horst IC, Anker SD, Babalis D, Roughton M, Coats AJ, Flather MD, van Veldhuisen DJ, SENIORS Investigators (2010) Influence of diabetes mellitus and hyperglycemia on prognosis in patients $>$ or $=70$ years old with heart failure and effects of nebivolol (data from the Study of Effects of Nebivolol Intervention on Outcomes and Rehospitalization in Seniors with heart failure [SENIORS]). Am J Cardiol 106:78-86

213. Komajda M, Carson PE, Hetzel S, McKelvie R, McMurray J, Ptaszynska A, Zile MR, Demets D, Massie BM (2011) Factors associated with outcome in heart failure with preserved ejection fraction: findings from the Irbesartan in Heart Failure with Preserved Ejection Fraction Study (I-PRESERVE). Circ Heart Fail 4:27-35

214. Borlaug BA, Paulus WJ (2011) Heart failure with preserved ejection fraction: pathophysiology, diagnosis, and treatment. Eur Heart J 2:670-679

215. Redfiled MM, Jacobsen SJ, Burnett JC, Mahoney DW, Bailey KR, Rodeheffer RJ (2003) Burden of systolic and diastolic ventricular dysfunction in the community. JAMA 289:194-202 